\title{
Host-Tree Chemistry Affecting Colonization in Bark Beetles
}

\author{
John A. Byers
}

\section{Introduction}

Bark beetles (order Coleoptera: family Scolytidae) comprise a taxonomic group of species that look similar although they differ widely in their ecology and biochemical adaptations to host trees. This diversity of bark beetle biology, in which each species is adapted to only one or a few host-tree species, has probably resulted from natural selection due to the great variety of trees and their biochemicals. It also is likely that each species of tree has coevolved various chemicals to defend against the herbivorous selection pressures of bark beetles and other insects (Erlich and Raven, 1965; Feeny, 1975; Cates, 1981; Berryman et al., 1985). Host-plant chemicals can be attractive, repellent, toxic, or nutritious to bark beetles and have effects on: (1) finding and accepting the host tree (host selection and suitability); (2) feeding stimulation and deterrence; (3) host resistance; (4) pheromone/allomone biosynthesis and communication; and (5) attraction of predators, parasites, and competitors of bark beetles.

Bark and ambrosia beetles contain at least 6,000 species from 181 genera worldwide (S.L. Wood, 1982). In the United States there are 477 species, and in North and Central America a total of 1,430 species occur from 97 genera. Bark beetles may have originated as early as the Triassic period (over 200 million years ago) on conifer hosts (S.L. Wood, 1982). Some Baltic amber dating from the Oligocene period ( 25 million to 30 million years ago) contains entrapped insects that appear identical to bark beetles from species of present-day genera such as Tomicus (S.L. Wood, 1982).

Since 1970 there have been over 3,800 research papers on bark and ambrosia beetles (BIOSIS Previews computer database, Philadelphia, PA). The genus Dendroctonus has been the most studied with over 1,196 papers published, primarily on four pest species of North America, $D$. frontalis, $D$. ponderosae, D. brevi- 
comis, and D. pseudotsugae. Other genera in order of studies were: Ips, Scolytus, Xyleborus, Trypodendron, Tomicus=Blastophagus, Pityogenes, Hypothenemus, Pityophthorus, Hylastes, and Gnathotrichus. The most studied Ips species (852 papers) also were pests, I. typographus of Europe, and the three North American species, I. paraconfusus = confusus, I. pini, and I. grandicollis. Scolytus multistriatus, vector of the Dutch elm disease, made up the majority of papers from this genus. Thus, it is clear that most biological knowledge of bark beetles derives from studies on relatively few pest species [these obligate and facultative parasites make up about $10 \%$ of scolytid species in the United States and Canada (Raffa et al., 1993)]. This focus on pests is appropriate, however, since only commonly occurring bark beetles that kill living trees or their parts would be expected to have a significant influence on evolution of the host tree and its chemistry.

\section{I.1. Colonization and Life Cycle of Bark Beetles}

Bark beetles are one of the few insect groups that as adults bore into the host plant for the purpose of laying eggs (S.L. Wood, 1982). Bark beetle adults and larvae in northern temperate climates generally feed on phloem/cambium (phloeophagy) of conifers (Gymnospermae). In the more tropical zones, the majority of species feed on wood (xylem) and on phloem of broad-leaved trees and shrubs (Dicotyledoneae). Monocotyledoneae are fed on by only a few tropical species of bark beetle. Species that feed on phloem are usually restricted to one or a few host species, whereas xylomycetophagous beetles (ambrosia beetles) that carry their own symbiotic fungi (which breaks down the xylem) may colonize a larger range of hosts (S.L. Wood, 1982).

Semiochemicals from both trees and bark beetles influence many behavioral actions of a bark beetle during its life cycle (Fig. 5.1) [for reviews see D.L. Wood (1982), Borden (1982), Lanier (1983), Birch (1984), Borden et al. (1986), Byers (1989a and 1989b), and Raffa et al. (1993)]. Most of the following presentation involves species in the genera Dendroctonus, Tomicus, Ips, and Pityogenes. In general, adults of these species overwinter in either forest litter (Ips, Pityogenes) or the brood tree (Dendroctonus, Ips, Pityogenes) (Fig. 5.1) (Lekander et al., 1977). In species that have several generations during the summer, emergence is from the brood tree. Tomicus piniperda, has a more complex life cycle in which adults overwinter in living, nonbrood trees (Salonen, 1973, Långström, 1983). After emergence the adults of all species attempt to locate a host tree (termed the dispersal flight), often by olfactory means, and determine if it is suitable for colonization and reproduction. This recognition of suitability may be in flight as well as after landing on the tree, as will be discussed later in section 2. In the monogamous Tomicus and Dendroctonus (subfamily: Hylesininae), the females select the host and a site to begin oviposition galleries that are excavated in the phloem. In contrast, males of polygynous Ips and Pityogenes (subfamily: Scolytinae) begin the entrance hole (attack) and later 


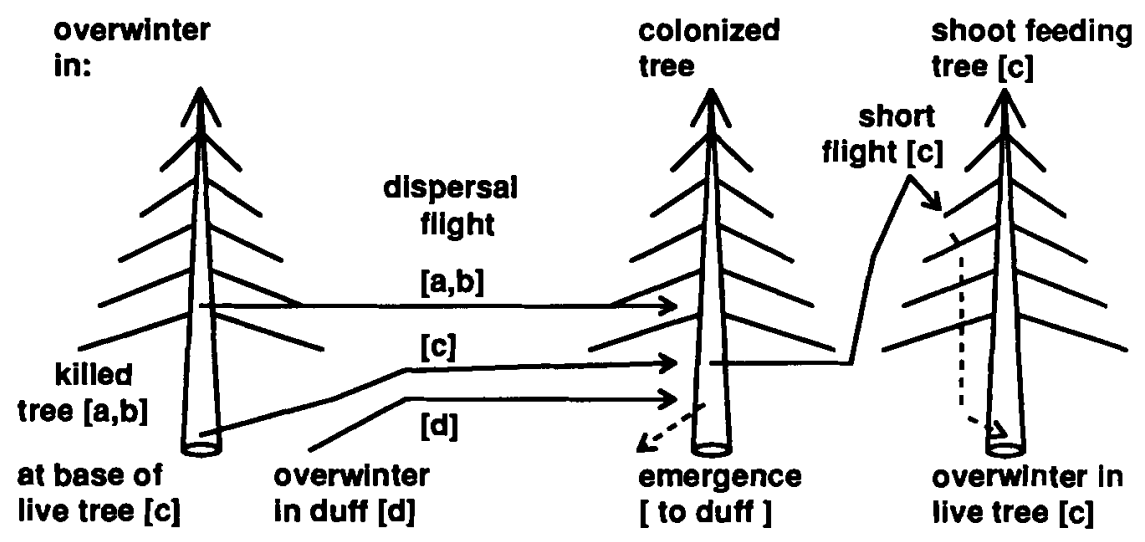

Figure 5.1. Generalized life cycles of phloem-feeding bark beetles. Dendroctonus (a), many Ips species, and Pityogenes, among other species (b) overwinter as larvae, pupae or callow (yellow) adults in the bark of the colonized tree. Tomicus piniperda (c) overwinter as adults in the outer bark of pines while some Ips species, e.g., 1. typographus overwinter in forest litter as adults (d). In the spring, beetles of all species disperse and search for suitable host trees in which to reproduce. Beetles successful in colonizing a tree lay eggs, these develop to larvae, pupate, and feed as callow adults until emergence. Depending on the season, beetles either overwinter or in warmer climates complete several generations during the summer. $T$. piniperda survive the summer by flying a short distance to the crowns of nearby trees and feeding in the stems of pine shoots (c); later in the autumn they crawl down the trunk and overwinter at the base (c).

accept several females. In most cases individuals of only one sex begin the attack, and release a species-specific blend of chemicals composing an aggregation pheromone (Byers, 1989b). However, in D. brevicomis both the female and the joining male each produce a unique and synergistic pheromone component that when combined elicit maximal attraction response (Silverstein et al., 1968, Kinzer et al., 1969). In $T$. piniperda there is no evidence of an aggregation pheromone (Byers et al., 1985; Löyttyniemi et al., 1988); instead, host-tree chemicals induce aggregation (discussed in section 2.3).

Once an individual or pair begins to release an aggregation pheromone, the likelihood that the tree is colonized depends on (1) the population level of beetles available for recruitment to the attack and (2) the resistance (health) of the tree and its ability to produce defensive resin (discussed in section 4). Beetles of many species have specialized areas of the integument or pouches where symbiotic fungi are carried and sometimes nourished until introduced inside the entrance tunnel where they grow into the tree (Happ et al., 1976; Whitney, 1982; Bridges et al., 1985; Paine and Stephen, 1987; Levieux et al., 1991). Some of the fungal species (genera Ceratocystis=Ophiostoma, Trichosporium) may attack the living tissues of the tree and paralyze the tree's ability to produce and exude resin for 
defense against the beetle (Mathre, 1964; Horntvedt et al., 1983; Paine, 1984; Raffa and Berryman, 1987; Paine and Stephen, 1987; Paine et al., 1988). Other fungal species of the beetle's mycangium grow in the galleries after the tree has been killed and appear important to the growth of the larvae (Bridges and Perry, 1985; Paine et al., 1988; Goldhammer et al., 1991). In ambrosia beetles, which generally attack unhealthy or dead trees, the adults and larvae feed on fungi lining the galleries instead of directly on the tree's tissues (Funk, 1970; Furniss et al., 1987; Kajimura and Hijii, 1992).

Successful colonization and reproduction by a bark beetle in a living tree requires release of enough aggregation pheromone to ensure the attraction of sufficient conspecifics to overwhelm the host-tree defenses. However, after killing the tree and securing mates, pheromone should not be released any longer in order for the beetles to avoid further competition for bark areas (Berryman et al., 1985). Thus, semiochemicals play a role in cooperation among beetles when killing the tree and in their avoidance of competition (discussed in section 5.4). Pioneer beetles that attack the tree first may suffer most from the tree's defensive resin, but these beetles may have no choice but to attack due to low fat reserves (discussed in 2). The later a beetle arrives in the colonization sequence of the host, the poorer is the quality of the bark substrate due to (1) space utilization by established conspecifics (intraspecific competition); and (2) degradation by microorganisms (discussed in sections 2.4 and 4).

Under the bark, females lay eggs which hatch to larvae that feed on the phloem for several weeks. Chemicals from the plant and from microorganisms could affect larval survival at this time, but little is known about these possible interactions. However, once the tree is dead, there can be no benefits to genotypes that produce harmful chemicals after death, unless these benefits operate through kin selection, a possibility for plants with limited seed dispersal (see Tuomi and Augner, 1993). The larvae pupate in the bark and become yellow, callow adults where they feed and mature until emerging. The beetles may begin a dispersal flight during the same season, or after overwintering in either the tree (Dendroctonus, Pityogenes and many Ips) or in the forest litter (I. typographus) (Fig. 5.1) (Lekander et al., 1977; Byers and Löfqvist, 1989). Tomicus minor and T. piniperda emerge from the bark and fly relatively short distances to the tops of pine trees where they bore into a shoot during the summer (Salonen 1973; Långström and Hellqvist, 1991) (Fig. 5.1). In the autumn, beetles of $T$. piniperda crawl down the trunk and bore into its base to overwinter, whereas $T$. minor overwinters in the litter (Salonen 1973; Långström, 1983).

\subsection{Sensory Organs}

Bark beetle sensory organs, including visual, olfactory and gustatory receptors, are studied not only to understand the ecological interactions between host trees and bark beetles such as host finding and acceptance, but also to understand 
many other behavioral processes such as communication, mating, feeding, and oviposition. The eyes of bark beetles are needed for flight, and in conjunction with antennae, for orientation toward or away from semiochemical sources. The eyes of bark beetles (e.g., Ips, Scolytus, and Pityogenes) have about 100-240 ommatidia, relatively less than many insects (Chapman, 1972; Byers et al., 1989a, see Figure 5.2). Two color receptor types in the eyes are indicated, based on electrophysiological recordings with a maximum at $450 \mathrm{~nm}$ (blue) and 520 $\mathrm{nm}$ (green)(Groberman and Borden, 1982). Observations of $I$. paraconfusus, $I$. typographus, D. brevicomis, P. chalcographus, and T. piniperda in flight chambers under dim red light or in complete darkness using an electronic vibration detector indicate they will not fly after dark (Lanne et al., 1987; Byers and Löfqvist, 1989; Byers, unpublished). Bark beetles are attracted more so to traps baited with host odor or pheromone that are placed next to tree trunk silhouettes than to traps without such visual stimuli, indicating that beetles orient to the tree trunk during landing (Moser and Browne, 1978; Borden et al., 1982; Tilden et al., 1983; Lindgren et al., 1983; Bombosch et al., 1985; Ramisch, 1986; Chénier

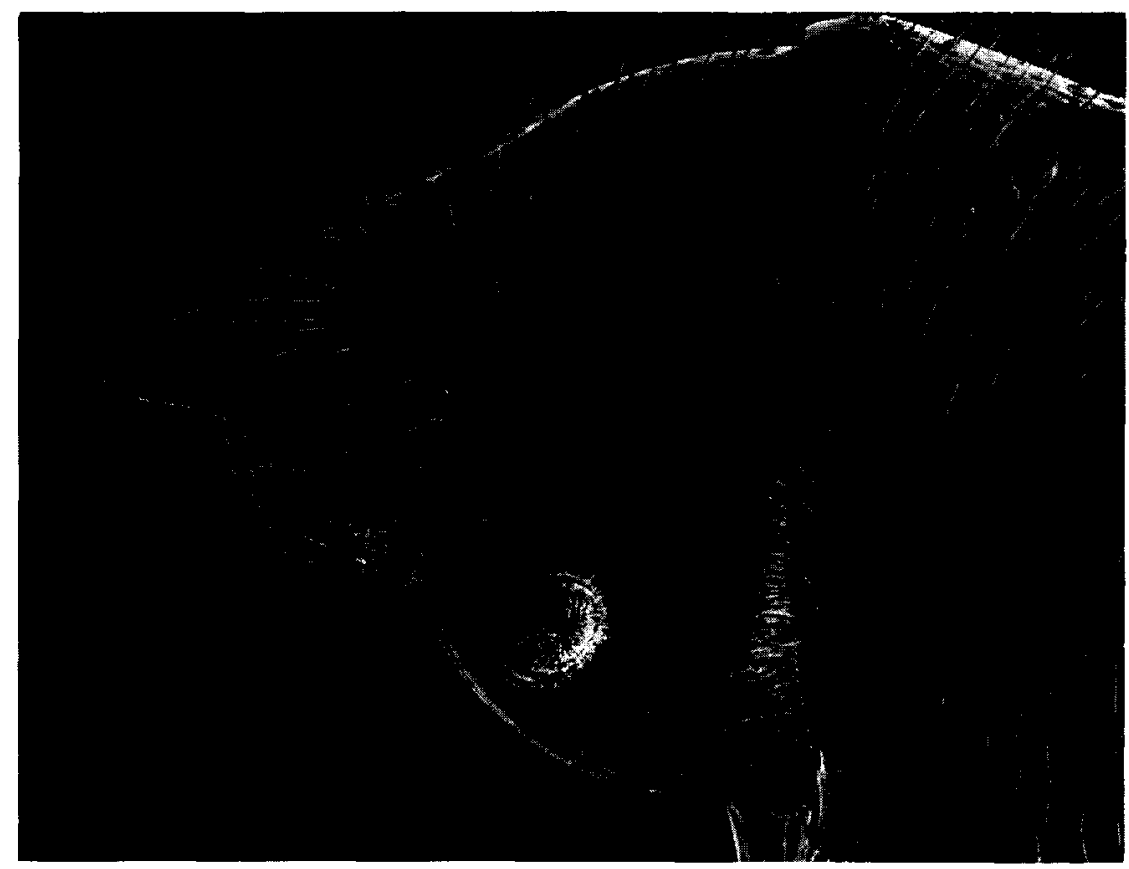

Figure 5.2. Lateral view of the head of Tomicus piniperda seen through the scanning electron microscope showing eye with ommatidia and antenna with club containing the olfactory and tactile sensory hairs (height of head is $800 \mu \mathrm{m}$, preparation by E. Hallberg and J. Byers). 
and Philogène, 1989). Beetles of some species prefer to land on horizontal silhouettes rather than on vertical ones of the same size (Pitman and Vité, 1969). Bark beetles have relatively poor visual acuity; for example, my observations of $T$. piniperda indicate that males must walk within $1 \mathrm{~cm}$ of a female beginning her entrance hole before they can detect her and initiate guarding behavior. The same individuals as well as those of $D$. brevicomis can be induced to drop off the tree by movements of the human body about $2 \mathrm{~m}$ away (about the same angle of resolution and relative size).

Little is known about the sensilla on the maxillary and labial palpi as well as surrounding mouthparts in bark beetles except for morphological studies of $D$. ponderosae and I. typographus (Whitehead, 1981; Hallberg, 1982). In these species there is clearly a large number of chemosensilla (Fig. 5.3) and these appear important for host selection and food discrimination (as will be discussed in sections 2 and 3). The tarsi and ovipositor in other insects have chemosensilla (Städler, 1984), but these have not been studied in bark beetles; it is assumed that all important chemosensory functions involve the mouthparts and antennae.

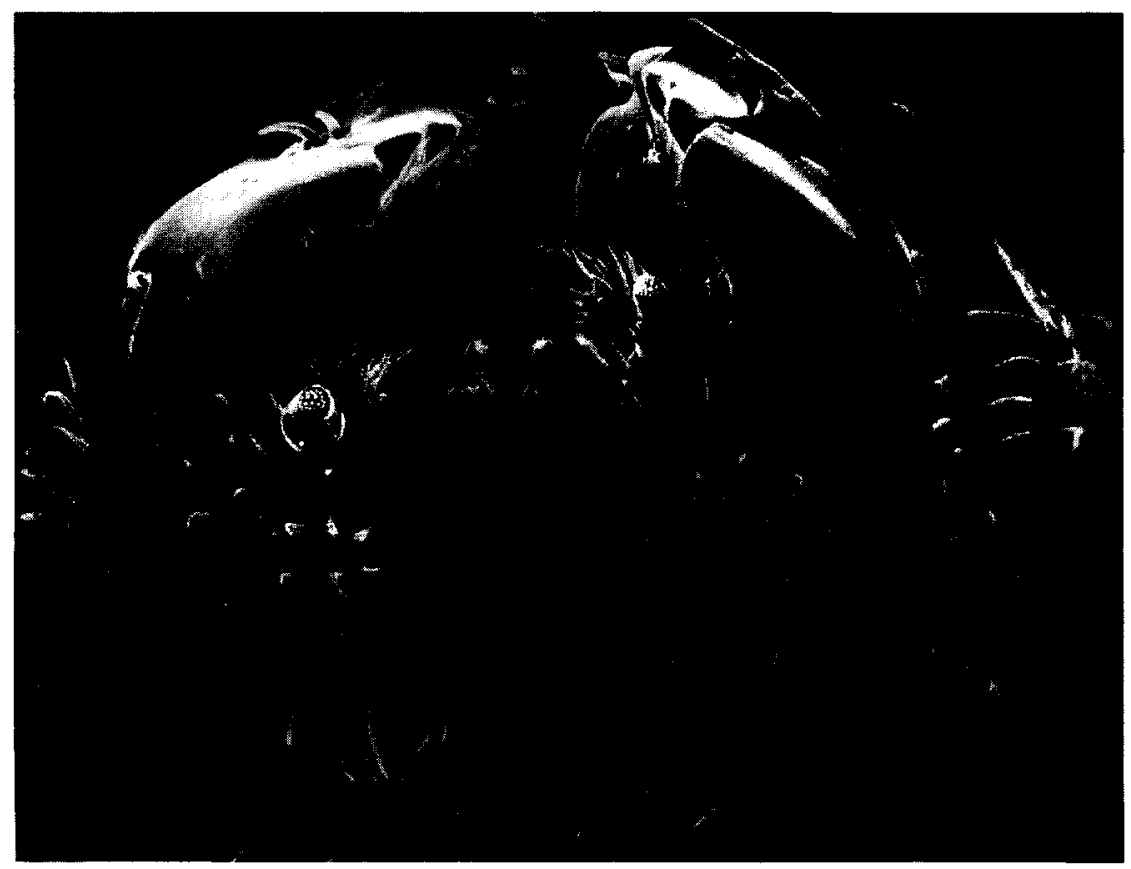

Figure 5.3. Ventral view of the mouth parts of Ips typographus seen through the scanning electron microscope showing the labial palpi (central pair) and maxillary palpi with their chemo- and mechanoreceptor hairs that are important in feeding behavior (maximum width is $700 \mu \mathrm{m}$, preparation by E. Hallberg and J. Byers). 
Most work has involved the antennae (Fig. 5.2), which are known to have sensilla responsive to volatile pheromone and host components as well as other airborne chemostimulants (Borden and Wood, 1966; Payne et al., 1973; Payne, 1979; Mustaparta, 1984; Faucheux, 1989).

The electrophysiological response of an insect to semiochemicals can be studied with the electroantennogram (EAG) of the whole antenna or the single-cell technique that measures responses of specific receptor cells (Payne, 1979). Each antennal receptor cell contains multiple acceptor sites that interact with the chemicals. Bark beetle olfactory cells on the antennae have been shown to be of several functional types, which probably are found in most species: (1) A highly specific type such as the ipsdienol-sensitive cells in $I$. paraconfusus and I. pini that is responsive only to one of two possible enantiomers (chemicals that cannot be structurally superimposed but otherwise are identical, see $\alpha$-pinene in Figure 5.4); (2) a pheromone-sensitive type that is also responsive to some other synergists or inhibitors such as the frontalin cells of $D$. frontalis (the cells have at least two acceptor types each specific for one enantiomer of frontalin, see

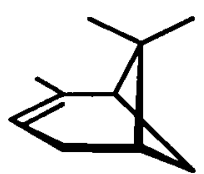

(S)-(-)- $\propto$-pinene

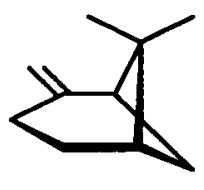

B-pinene<smiles>C=CC(=C)CCC=C(C)C</smiles>

myrcene

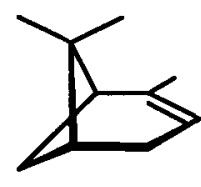

$(R)-(+)-\propto-$ pinene

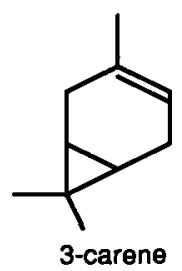<smiles>C=C1C=CC(C(C)C)CC1</smiles>

B-phellandrene

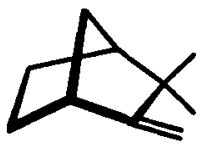

camphene<smiles>CC1=CCC(=C(C)C)CC1</smiles>

terpinolene<smiles>C=C(C)C1CC=C(C)CC1</smiles>

limonene

Figure 5.4. Major monoterpenes of conifers. Note that the enantiomers of $\alpha$-pinene are identical except that they are non-superimposable (mirror images). Camphene, $\beta$-pinene, 3 -carene, $\beta$-phellandrene, and limonene also have two enantiomers, although only (-)$\beta$-pinene and (+)-3-carene are found in trees (Mirov, 1961). Myrcene and terpinolene are achiral. 
Figure 5.5), and (3) generalist types that respond to host monoterpenes as well as pheromones to some extent (Mustaparta et al., 1980; Payne et al., 1982; Dickens et al., 1985; Dickens, 1986).

The technique of differential adaptation first attenuates an electrophysiological response by exposing a receptor cell (or antenna) to a high concentration of a compound until specific acceptor sites are saturated, then these sites are exposed to a different volatile to see if any responses are elicited (Payne and Dickens, 1976; Payne, 1979; Dickens et al., 1985). By using this technique with singlecell recordings it was shown that $D$. pseudotsugae has at least four olfactory cell types (Dickens et al., 1985). Three types are each most sensitive to either 3methylcyclohex-2-en-1-one (3,2-MCH), seudenol, or frontalin (Fig. 5.5), although they are all stimulated somewhat by all of these pheromone components. The fourth cell type is most sensitive to host compounds released by excavating beetles and that are synergists of pheromone components. Acceptors can be specific for one enantiomer of a chiral mixture (Payne et al., 1983) and there may be either only one type of acceptor per cell [e.g. (+)- or (-)-ipsdienol in I. paraconfusus (Mustaparta et al., 1980)] or both types of chiral acceptors on the same cell [e.g. (+)-and (-)-frontalin in D. frontalis (Payne et al., 1982) and D. pseudotsugae (Dickens et al., 1985)].

The antennae of both sexes of $I$. paraconfusus are equally sensitive as measured with the electroantennogram (EAG) to natural pheromone and to (+)-ipsdienol (Light and Birch, 1982). However, the males have been shown to be relatively less attracted by higher concentrations of synthetic pheromone components, and they were not as likely to fly directly toward the pheromone source as were females (Byers, 1983c). Thus, the sexual differences in behavioral response of I. paraconfusus to aggregation pheromone appear to be the result of differences in central nervous system (CNS) integration rather than differences in peripheral receptors. Cis-verbenol (Fig. 5.5) elicits a similar electrophysiological doseresponse curve for both sexes of I. typographus, but some sexual differences exist for responses to methyl butenol (Dickens, 1981). Similar to I. paraconfusus, males of I. typographus orient less directly to pheromone than females during the approach and landing on the host (Schlyter et al., 1987c); this behavioral difference could be due either to CNS differences between the sexes or to the lesser receptor sensitivity of males to methyl butenol. Mustaparta et al. (1980) have shown that eastern U.S. populations of $I$. pini have separate cells for each of the two ipsdienol enantiomers that are synergistic attractants (Lanier et al., 1980). However, the exposure of the two cells to the enantiomers together did not synergistically increase the nerve impulse rate, and so it was concluded that synergism in this case acts at the CNS level.

Of the three or four receptor types found in most species it appears that individual receptors within a type also can vary in their response spectrum to various chemicals (Dickens, 1986; Dickens et al., 1985; Mustaparta et al., 1980, 1984; Tommerås et al., 1984). In the few cases so far known, the cells responsive 


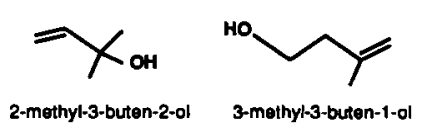

(3S,4R)-4-methyl-3-heptanol
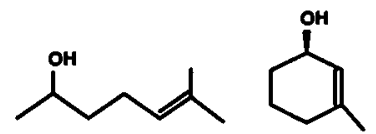

年<smiles>CC1=CC(C)(C)C=C(O)C1=O</smiles>

(S)-(t)-sulcatol (R)-seudenol (3,2)-MCH lanierone

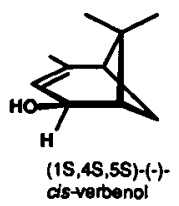<smiles>CC1C[C@H](O)[C@H]2C[C@@H]1C(C)(C)C2C</smiles>

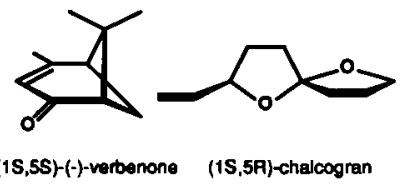<smiles>[CH][C@@H](CC(=C)C=C)CC(C)C</smiles><smiles>C=CC(=C)CC=CC(C)(O)C(C)(C)O</smiles><smiles>C=CC(=C)CC/C=C(/C)CO</smiles><smiles></smiles><smiles>CCC12OC3CC[C@@]1(CO3)O2</smiles><smiles>CCCCC/C=C/C=C/C(=O)OC</smiles>
$(1 \mathrm{R}, 5 \mathrm{~S}, 7 \mathrm{R})-(+1)$ $(1 \mathrm{~S}, 5 \mathrm{R}, 7 \mathrm{~S})-(-)-$ exo-brevleomin

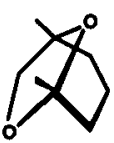

(1S,5R)-(-)

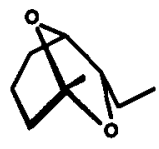

(1R,5S,7R)-(+)-

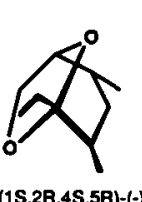
(1S,2R,4S,5R)-(-)

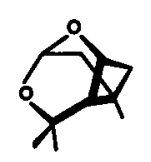

(1R,4S,5R,7R)-(+)

Figure 5.5. Pheromone components of bark beetles. Key: aggregation component (a), inhibitor of aggregation (i). Row 1: 2-methyl-3-buten-2-ol (a, I. typographus); 3-methyl3-buten-1-ol (a, I. cembrae), 4-methyl-3-heptanol (a, S. multistriatus). Row 2: sulcatol (a, G. sulcatus, G. retusus); seudenol (D. pseudotsugae, D. rufipennis, D. simplex); MCH (i, D. pseudotsugae); lanierone (a, I. pini). Row 3: cis-verbenol (a, I. paraconfusus, I. typographus, I. calligraphus); trans-verbenol (a, D. ponderosae, $T$. minor; i, $D$. brevicomis); verbenone (i, Dendroctonus); chalcogran (a, Pityogenes). Row 4: ipsenol (a, Pityokteines curvidens, and many Ips: e.g. I. paraconfusus, I. grandicollis), ipsdienol (a, many Ips, e.g. I. paraconfusus, I. duplicatus, I. pini, I. calligraphus, I. avulsus); amitinol (a, I. amitinus); E-myrcenol (a, I. duplicatus). Row 5: (+)-exo-brevicomin (a, D. brevicomis, Dryocoetes); (-)-exo-brevicomin (a, Dryocoetes); methyl decadienoate ( $P$. chalcographus). Row 6: frontalin (a, many Dendroctonus); endo-brevicomin (i, $D$. frontalis); multistriatin (a, S. multistriatus); lineatin (a, T. lineatum). References to above pheromones are in reviews by Borden (1982) and Byers (1989b), and the following (Bakke, 1975; Baker et al., 1977; Lanne et al., 1987; Borden et al., 1987; Byers et al., 1989b, 1990a, 1990b; Teale et al., 1991; Camacho et al., 1993). 
to host-plant chemicals are present in both sexes, but the host-selecting sex (males of Ips or females of Dendroctonus) has a lower threshold to plant compounds (Dickens, 1981, 1986; Dickens et al., 1983). However, the role of plant compounds in long-range orientation of many species of Ips is not certain (as discussed in section 2). Probably short-range behaviors on the bark (e.g., gustatory responses) are influenced by host volatiles, but this also is poorly understood.

Some bark beetles have receptors sensitive to compounds they do not produce but are found in several other bark beetles as pheromone components (Tommerås et al., 1984). Lanne et al. (1987) showed compounds not found in $T$. piniperda (exo-brevicomin, ipsenol, and pheromone components of other bark beetle species) elicited an EAG response in the beetle. Some of these compounds are found in competing species of bark beetles, but other compounds are probably found only in species colonizing nonhost trees (e.g., Norway spruce). Three sympatric species of the southem United States, Ips avulsus, I. calligraphus, and I. grandicollis, are most responsive electrophysiologically to components of their own pheromones (ipsenol, ipsdienol, cis-verbenol); but they can also respond to components of their sibling species as well as frontalin and verbenone from $D$. frontalis and $\alpha$-pinene from their host pine released by activities of other species (Smith et al., 1988).

The difficulties with electrophysiological methods for unraveling ecological phenomena during host finding and tree colonization are threefold: (1) The electrical measurements may not be correlated to the behavior of interest; (2) the nerve impulses vary between cell types (Mustaparta et al., 1980) of which all are not located and tested; and (3) the electrical patterns are further integrated in the complexity of the CNS.

\subsection{Genetic-Based Variation of Host Plants and Bark Beetles}

Evolution of plant chemicals that increase the tree's resistance to colonization by a bark beetle population requires that (1) the plant chemicals are detrimental to the beetle; (2) the host chemistry is genetically determined; (3) populational variation in genotypes of these trees exists; and (4) the bark beetle exerts selection pressure on the tree (by killing or reducing fertility). The beetle population should coevolve, if possible, by shifting their genotype frequencies to those that offer more protection against the plant chemicals. The disadvantage for the tree in this "arms race" is that the beetle population may undergo between 25 and several hundred reproductive cycles compared to one generation for the tree, thus the chances for beneficial genetic recombinations and mutations are greater for the insect. Mutant bark beetles of greater endurance would in the beginning have help in killing "resistant" trees from "normal" beetles (that would die more frequently), until gradually mutant beetles would become the most frequent genotype.

Many chemicals in the tree that affect colonization by bark beetles may not 
be under selection pressure from the insect. Chemicals that are required in physiological processes by the tree may not be readily dispensed with in an evolutionary response to evade their secondary use by insects. For example, various sugars are transported by the phloem and required by the tree for growth; the same sugars may be feeding stimulants for the beetle. If the tree could dispense with the sugars it would become undesirable as food. However, this is unlikely since all trees use sugars (photosynthate) in many biosynthetic pathways (e.g., cellulose).

A theory accounting for the evolution of bark beetle races of $D$. ponderosae each adapted to feeding in ponderosa, lodgepole, or limber pines has been presented by Sturgeon and Mitton (1986). The three species of trees occur together in Colorado and are colonized by $D$. ponderosae. Five enzymes, each varying in several isozymes that migrate differently in electrophoresis gels, were investigated among beetles taken from the three host-tree species. The isozyme frequencies, which represent different alleles at a polymorphic loci, were different among the beetles from the three hosts. The beetles from limber pines were less heterozygous than beetles from the other two hosts. Furthermore, heterozygous beetles were less numerous than expected, suggesting that selection had occurred against these beetles because they were not well adapted to any of these three hosts. If mating between host populations was restricted, for example by different emergence times due to differing development times in each host, then host races could develop. However, no host-related differences in isozyme variation were found for $D$. frontalis from shortleaf or loblolly pines (Namkoong et al., 1979). Langor et al. (1990) naturally reared $D$. ponderosae from limber and lodgepole pines and crossbred them in each species again. They found small reductions in egg production and hatching when pairs were mated from different pine sources compared to the same host source, although beetles from all possible crosses could reproduce-indicating the host races did not appear reproductively isolated (at least under epidemic conditions), thus precluding speciation.

Host trees also vary in monoterpenes which are undoubtedly genetically regulated. Tree monoterpenes appear to affect colonization of bark beetles in a variety of ways (discussed in sections 2 to 6). Monoterpenes (examples shown in Figure 5.4) vary little within a tree, moderately between trees of the same species within a habitat, and greatly between geographic regions; the largest differences are evident among conifer species (Mirov, 1961; Smith, 1964, 1967, 1968, 1969; Sturgeon 1979; Byers and Birgersson, 1990). Genetic differences among beetles over large geographic areas may, in part, reflect the variation in the monoterpene composition of their host. For example, bark beetle populations of $D$. ponderosae, $D$. frontalis, D. terebrans, and I. calligraphus from different regions when analyzed for certain enzymes by electrophoresis were found to vary genetically within a species (Stock et al., 1979; Namkoong et al., 1979; Stock and Amman, 1980; Anderson et al., 1979, 1983).

There is also semiochemical evidence that bark beetles vary genetically over 
geographic regions. I. pini varies geographically in their production of and response to pheromone enantiomers of ipsdienol (Lanier et al., 1972, 1980; Miller et al., 1989). Two populations of $D$. pseudotsugae from Idaho (inland) and coastal Oregon were found to differ in isozyme frequencies (Stock et al., 1979). These two populations also have a number of possible genetic-based differences in behavioral responses to semiochemicals: (1) ethanol is much more attractive to inland beetles (Pitman et al., 1975; Rudinsky et al., 1972); (2) transverbenol inhibits pheromonal response in inland beetles but not in coastal beetles (Rudinsky et al., 1972); and (3) the inhibitor 3-methylcyclohex-2-en-1-one (3,2$\mathrm{MCH}$ ) (Fig. 5.5) is produced by coastal females but not in inland females (Pitman and Vité, 1974; Rudinsky et al., 1976). Borden et al. (1982) found Trypodendron lineatum response to host-released ethanol and $\alpha$-pinene differed between continents. Western North American beetles responded weakly to ethanol plus $\alpha$ pinene and these compounds did not enhance a strong attraction to the aggregation pheromone lineatin; whereas beetles in England were similarly attracted to lineatin or to the two host volatiles, and their combination was synergistically active.

\section{Host-Plant Selection}

Bark beetles and associated beetles feeding or living in trees must locate a suitable host from among the relatively few scattered widely in the forest. The host tree is restricted usually to one or a few species and in most cases the insects seek weakened, less resistant trees, or trees that are in the initial stages of death and decay. Thus, it is expected that species have evolved behavioral responses to volatile host-plant chemicals that indicate the presence of a suitable host in which reproduction can occur.

Bark beetles emerge from the forest litter or from the brood tree and search for suitable hosts in a dispersal flight. The distances and paths of these dispersal flights are poorly known and difficult to observe. In some experiments, beetles are painted or marked with fluorescent powder and released to be recaptured by pheromone-baited traps: I. typographus, the major pest of Norway spruce, Picea abies, was found to disperse up to $8 \mathrm{~km}$ (Botterweg, 1982) and Ips sexdentatus up to $4 \mathrm{~km}$ (Jactel, 1991). Other mark-recapture studies have found Ips and $T$. lineatum disperse generally downwind (Anderbrant, 1985; Salom and McLean, 1991; Jactel, 1991) probably due to the wind-drift component, but in light winds the flight is nondirectional (Salom and McLean, 1989). Jactel and Gaillard (1991) flew I. typographus on rotary flight mills connected electronically to a computer. They found that $50 \%$ of $I$. typographus can fly more than $20 \mathrm{~km}$ and $10 \%$ more than $45 \mathrm{~km}$ based on about 50 interrupted flights. In another study, the longest continuous fight on a flight mill was $6 \mathrm{hr}$ and 20 min (Forsse and Solbreck, 1985). This suggests that a few I. typographus could fly up to $46 \mathrm{~km}$ at a speed of $2 \mathrm{~m} / \mathrm{s}$ without resting (Byers et al., 1989a), and even further when blown by 
winds. Of course, many individuals would be attracted to hosts or attacked trees much nearer their dispersal origin (Lindelöw and Weslien, 1986).

Several bark beetle species ( $D$. pseudotsugae, S. multistriatus, T. lineatum, and $I$. sexdentatus) may require a period of flight exercise before they are fully responsive to pheromone or host attractants (Graham, 1959; Atkins, 1969; Bennett and Borden, 1971; Wollerman, 1979; Choudhury and Kennedy, 1980; Jactel, 1991). Other species such as $D$. ponderosae, $D$. brevicomis, 1 . paraconfusus, Pityogenes chalcographus, and $T$. piniperda are responsive to semiochemicals immediately after beginning flight (Gray et al., 1972; Byers and Wood, 1980; Byers et al., 1985, 1990a). I. typographus emerging from the duff responded to nearby pheromone traps without the need for an extended period of flight exercise (Lindelöw and Weslien, 1986), although experiments in the laboratory indicate that response increases with the length of flight exercise (Schlyter and Löfqvist, 1986). Bark beetles generally swallow air and inflate their ventriculus before flight, and this may function as a barometric air pressure receptor to indicate imminent stormy weather (Lanier and Burns, 1978). Artificial changes in the air pressure reduced responsiveness of $S$. multistriatus to the host compound $\alpha$-cubebene and pheromone components (Lanier and Burns, 1978).

Finding and accepting host plants by insects has been reviewed by Miller and Strickler (1984). They present a model (their Fig. 6.1) by Dethier (1982) where the decision by the insect whether to accept the plant is dependent on external (olfaction, vision, mechanoreception, and gustation) stimulatory and inhibitory inputs balanced against internal excitatory and inhibitory inputs. A graphical, and simplified, model of host acceptance is shown in Figure 5.6 that is directly applicable to bark beetles. In this model, as the bark beetle flies around searching for suitable host trees (usually trees already under attack by conspecifics) they use up energy reserves of lipids (Atkins, 1969; Thompson and Bennett, 1971) and probably become increasingly "desperate" to accept a host. The beetle may by chance encounter several hosts during the dispersal flight that are more or less suitable for reproduction. The beetle will accept the host if the combination of the host suitability and fatigue level of the beetle is above the curve (Fig. 5.6); otherwise the beetle will continue searching for more suitable hosts. The curve is asymptotic to the $\mathrm{Y}$-axis for those beetles that require flight before responding to semiochemicals, whereas the curve would intersect the $\mathrm{Y}$-axis for species that are immediately responsive after emergence. The suitability of the host is determined by the nutritional quality as well as the density of established attacks by the same or other species of bark beetle that indicate the potential for damaging competition.

\subsection{Theories of How Bark Beetles Find Suitable Host Trees}

There are two theories on how bark beetles find suitable host trees (McMullen and Atkins, 1962). The first is that they locate such trees by orienting over 


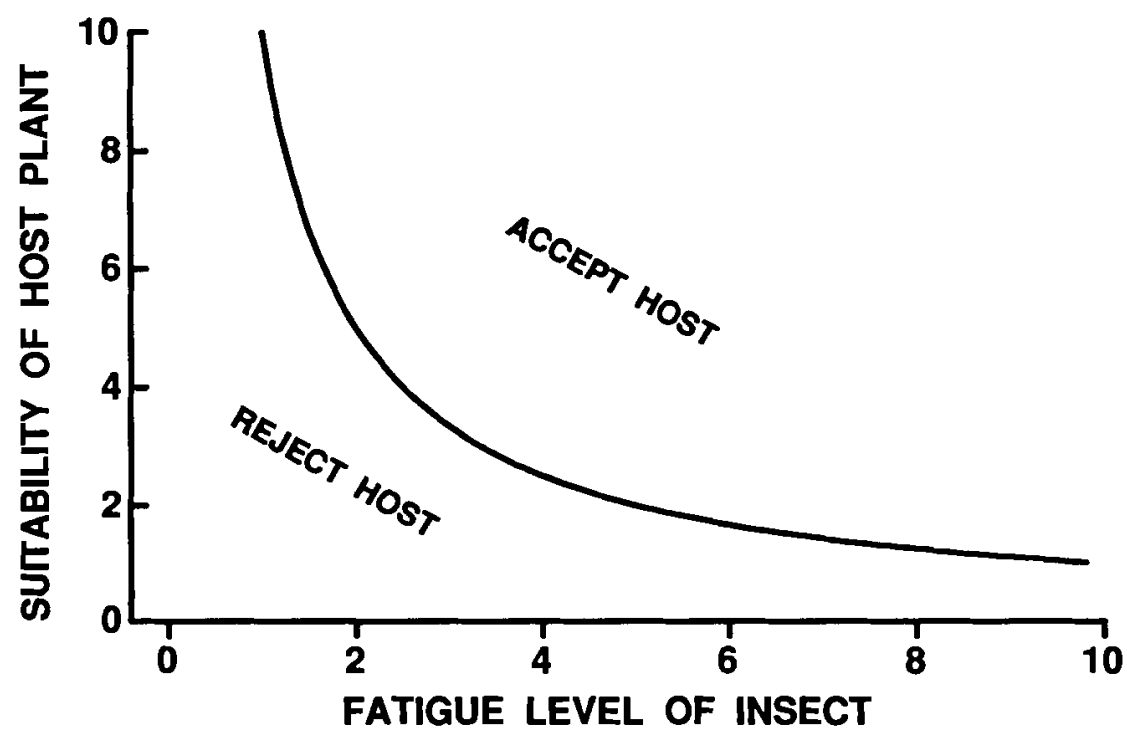

Figure 5.6. Theoretical curve for the acceptance of host trees by bark beetles depending on prerequisite flight exercise (asymptotic Y-axis), level of fatigue (amount of flight) and suitability of the host for reproduction (which depends on nutritional quality and density of colonization by competing bark beetles).

several meters to volatile chemicals usually released by damaged or diseased trees (called primary attraction). The second theory is that beetles fly about and encounter suitable host trees at random, whereupon they land and test them by short-range olfaction or gustation. The two theories are not mutually exclusive, and one or the other may primarily operate in a particular species. In California, host finding by the important pests $D$. brevicomis and $I$. paraconfusus is thought to be a random process. Ponderosa pines that were killed by freezing with dry ice and screened to prohibit bark beetle attack, did not have higher landing rates for the prevalent $D$. brevicomis and $I$. paraconfusus bark beetles (among other species) than did living trees. Landing rates on diseased and healthy trees also were similar; it was estimated that each tree in the forest was visited by about one $D$. brevicomis beetle each day (Moeck et al., 1981; D.L. Wood, 1982). Logs of freshly cut ponderosa pine placed in sticky screen traps did not catch beetles of these species, while at the same time high numbers were attracted to synthetic pheromone or infested logs (Moeck et al., 1981).

In addition to $I$. paraconfusus and $D$. brevicomis, many species probably visit trees at random and determine whether they are an appropriate host after landing. For example, Scolytus quadrispinosus was caught equally on traps placed in host shagbark hickory, Carya ovata, and nonhost white oak, Quercus alba (Goeden and Norris, 1965). Beetles also may test the resistance of a host tree when they 
bore into the bark during an attack. Berryman and Ashraf (1970) found attacks by Scolytus ventralis in the basal section of $74 \%$ of grand fir examined, while only $3.5 \%$ of these trees were killed and colonized. Most unsuccessful attacks were abandoned before beginning the gallery. The attacks on grand fir appeared random during the early part of the flight period before aggregations resulted. Hynum and Berryman (1980) caught $D$. ponderosae in traps on $96 \%$ of the lodgepole pines $(P$. contorta) sampled, but only $66 \%$ of these pines were killed. Also, they found no differences in landing rates between killed and surviving lodgepole pines or between host and nonhost trees. A direct relationship between the number of $D$. ponderosae caught on unattacked trees and the number of trees upon which beetles landed was found in a study of 123 lodgepole pines (Raffa and Berryman, 1979). I. grandicollis landed equally on sticky traps on trees judged resistant or susceptible based on crown area (Witanachchi and Morgan, 1981). However, Schroeder (1987) found a higher average of 35 T. piniperda landing on lower vigor Scots pine, $P$. sylvestris (as judged by less crown area), than on higher vigor trees (mean of 22). These differences could be due to secondary release of monoterpenes by beetles boring in the low vigor trees that were less able to resist attack.

There is some evidence that I. typographus is weakly attracted to host volatiles (Austarå et al., 1986; Lindelöw et al., 1992) or monoterpenes such as $\alpha$-pinene (Rudinsky et al., 1971), but other studies have not observed any attraction to host volatiles or synergism of pheromone and host volatiles (Schlyter et al., 1987a). A computer model by Gries et al. (1989), in which "beetles" must take a series of flights between trees in a grid (each flight to one of eight neighboring trees) and test each tree for suitability, showed that few beetles would find the widely scattered hosts designated as susceptible. Thus, they concluded that a mechanism of long-range primary attraction would be required for maintenance of the population. However, a more recent computer model, in which beetles fly more naturally among randomly dispersed susceptible trees, can be used to show that a significant proportion of the population will find the susceptible trees (of actual trunk diameter) by chance interception (Byers, 1993b). If beetles then test the defenses of the potential host (although this rarely has been observed, see section 4) then weaker, more susceptible, trees will not exude adequate resin and allow the beetle to produce aggregation pheromone. According to the later model, this will in effect greatly increase the effective "radius" of the tree so that the remainder of the population can quickly find and colonize these trees (Byers, 1993b).

In addition to the random and host-volatile theories, some bark beetles may find weakened and susceptible host trees by orienting to volatiles produced by competing insect species during colonization. The volatiles can be host compounds that virtually any bark beetle would release upon attack (e.g., monoterpenes) or pheromone components of these other species. For example, D. brevicomis responds to pheromone components of I. paraconfusus (Byers and Wood, 
1981b); I. typographus responds to exo-brevicomin (from D. micans and Dryocoetes spp.) (Borden et al., 1987) when combined with its pheromone components (Tommerås et al., 1984); and several sympatric species of Ips in the southeastern United States are cross-attracted to infested pine logs (Birch et al., 1980b).

\subsection{Orientation Mechanisms for Attraction to Semiochemicals}

Primary attraction to the host tree can be considered to occur over a long or short range. The concept of range differs between authors and depends also on the insect considered. Here I consider long-range attraction for bark beetles to be flight orientation over several meters to a semiochemical source. In reality the division is arbitrary, since bark beetles may orient over practically any distance depending on release rate of semiochemical, although at higher release rates the insect may not closely approach the source due to adaptation (Baker et al., 1988). However, the concept of range is still helpful since at natural release rates the beetle will have a range of orientation distances which can be considered long or short range in comparison to orientation distances elicited by other semiochemicals.

Attraction to pheromone is certainly long range. Three parallel lines spaced $4.6 \mathrm{~m}$ apart and hung with sticky screens spaced every $1.5 \mathrm{~m}$ intercepted $I$. paraconfusus in a $\mathrm{V}$-shaped pattern narrowing to a pheromone source of 50 males boring in a pine $\log$ (Byers, 1983c). In this experiment beetles appeared to be orienting over a distance of at least $17 \mathrm{~m}$. S. quadrispinosus beetles were intercepted by passive traps $12 \mathrm{~m}$ from a girdled hickory tree that was attracting these beetles (Goeden and Norris, 1964). The distance over which beetles respond anemotactically depends primarily on the release rate of the volatile (under mild wind conditions). In Denmark, I once observed $I$. typographus flying slowly upwind ( 0 to $0.5 \mathrm{~m} / \mathrm{s}$ ground speed) in $3 \mathrm{~m} / \mathrm{s}$ gusty winds to a large fallen spruce tree under massive attack. During their orientation to pheromone, beetles were flying at 3-6 m height from at least as far as $50 \mathrm{~m}$ downwind from the tree. Jactel (1991) estimated that the maximum attraction distance of $I$. sexdentatus to pheromone-baited traps was $80 \mathrm{~m}$.

Byers et al., (1989a) proposed the "effective attraction radius" (EAR) as an index of attraction strength for a semiochemical release rate from a trap. The EAR is the radius that a trap would need to be enlarged, as a spherical passive trap, in order to intercept as many dispersing insects as were actually caught on the trap when baited with attractant (Byers et al., 1989a). For example, the EAR of $T$. piniperda to a blend of three host monoterpenes, released at rates equivalent to a cut $\log$ of Scots pine from each of 10 traps along a 12-m high pole, was largest at the lowest trap (EAR $=1.3 \mathrm{~m}$ ). The same design found an EAR of $3.2 \mathrm{~m}$ for $I$. typographus response to a blend of its pheromone components (Fig. 5.5). These comparisons indicate that the effective attraction radius can be larger 
for a pheromone than for host volatiles. However, both these values would be greater at higher chemical release rates.

The optomotor anemotaxis mechanism for orientating to pheromone sources proposed for insects, especially moths (David et al., 1982; Baker, 1989), also appears to function in bark beetles (Choudhury and Kennedy, 1980). In this theory, a bark beetle attempts to fly directly upwind when in contact with a packet of pheromone-laden air of the plume, but casts (flies from side to side with respect to the source) when contact is lost. The beetle senses the wind direction while flying by observing the ground below: in no wind, or head-on wind, the ground moves directly underneath during flight. However, if the visual ground field also moves from right to left somewhat, for example, then wind is coming from the left, and the beetle turns to the left to minimize the transverse ground shift and keep the ground moving directly underneath so that the insect heads upwind and toward the pheromone source.

Short-range attraction could be considered to occur within one meter such as when flying along the trunk as I have observed for $T$. piniperda; however, after landing the beetle must use a different mechanism than optomotor anemotaxis. During walking the ground does not move under the beetle due to wind, but the beetle probably can sense wind direction by mechanoreceptors and use pheromone-modulated anemotaxis combined with "casting" or circling movements to locate the odor source. Beetles walking in an arena with laminar airflow respond to a point source of synthetic pheromone (or air from an attacked log) by walking directly upwind within the odor plume. If they happen to walk outside the plume as it narrows to the source, they would experience a concentration gradient decline as they walked. By turning slightly with respect to the upwind angle (as detected by tactile hairs) they would either soon recontact the odor or the concentration would further decline. In the latter case they could reverse the angle or continue turning in a circle which would bring them into odor contact, whereupon they could walk directly upwind again. This mechanism is consistent with observations of beetles responding to pheromone or host odors in a laboratory olfactometer [see Birch (1984)] for species of Ips, Dendroctonus, Tomicus, and Pityogenes (Byers et al., 1979; Byers and Wood, 1981b; Lanne et al., 1987; Byers, 1983c; Byers et al., 1990a, 1990b). Borden and Wood (1966) show tracings of tracks of $I$. paraconfusus walking upwind to pheromone.

Akers (1989) studied orientation of $I$. paraconfusus to pheromone in a laboratory olfactometer. He found that beetles increased their counterturning rate (turning left, then right, etc.) in relation to a decline in the rate of concentration increase as they approached the source. In a second study, beetles walked in all directions with respect to the wind without pheromone present, but when in a pheromone plume they decreased their angle to the source (although usually not heading directly upwind) and their turning rate increased (Akers and Wood, 1989a). These generally upwind walking angles and increased turning rates would be expected for beetles orienting to a pheromone source. An important finding 
was that beetles did not usually walk directly upwind but at slightly different angles. This was attributed to inaccurate anemotaxis rather than a preference for a specific angle with respect to wind and pheromone (anemomenotaxis). Bark beetles appear to have a third mechanism for finding odor sources in the absence of wind. Akers and Wood (1989b) discovered that $I$. paraconfusus can find pheromone sources in still air. The turning rate increased, but only slightly, as the beetles approached the diffusion source, while the mean heading angle to the source decreased as the beetles neared the source (but not for the last 15 $\mathrm{cm})$. Thus, bark beetles are able to use any of several orientation mechanisms, depending on the environmental context, to locate hosts and mates.

\subsection{Host-Plant Volatiles Attractive to Bark Beetles}

Host volatiles are attractive to a number of forest scolytids including species in the genera Scolytus, Dendroctonus, Hylurgops, Trypodendron and Tomicus (Goeden and Norris, 1964; Rudinsky, 1966; Meyer and Norris, 1967a; Moeck, 1970; Byers et al., 1985; Lanne et al., 1987; Volz, 1988; Lindelöw et al., 1992; Hobson et al., 1993). Species of bark beetle that regularly attack and kill living trees (termed aggressive) have been shown invariably to possess an aggregation pheromone, usually of two or more components, but are weakly, if at all, attracted by host volatiles alone (Vité and Pitman, 1969; Byers, 1989b). However, socalled secondary bark beetle species (those that arrive later after the tree has already been killed by the aggressive bark beetles or that feed as saprophytes in decaying trees) may not use an aggregation pheromone, but generally are strongly attracted to either host monoterpenes, ethanol, or a combination (Kohnle, 1985; Klimetzek et al., 1986; Schroeder, 1988; Schroeder and Lindelöw, 1989).

Ethanol, probably released by microorganisms in decaying woody tissue (Graham, 1968; Moeck, 1970; Cade et al., 1970) and stressed plants (Kimmerer and Kozlowski, 1982), is attractive to a wide variety of species of bark beetles (Moeck, 1970, 1981; Magema et al., 1982; Montgomery and Wargo, 1983; Kohnle, 1985; Klimetzek et al., 1986; Schroeder 1987, 1988; Schroeder and Eidmann, 1987; Phillips et al., 1988; Volz, 1988; Chénier and Philogène, 1989; Schroeder and Lindelöw, 1989; Byers, 1992a). Primary alcohols other than ethanol have not been reported as being attractive to scolytids. However, only a few studies have tested methanol (Moeck, 1970; Montgomery and Wargo, 1983; Byers, 1992a); longer-chain alcohols up to hexanol did not attract scolytids in Sweden when they were known to be flying (Byers, 1992a). Electroantennogram (EAG) responses of $T$. piniperda to a series of straight-chain alcohols indicated that the antennae respond increasingly with longer chain length up to a maximum between pentanol and heptanol and then decrease (Lanne et al., 1987). The response spectrum could be due in part to differences in volatility. Thus, although ethanol plays a role in host selection (discussed subsequently), the EAG response for ethanol is lower than for longer-chain alcohols (which 
probably are not involved in behavior). Ethanol and $\mathrm{CO}_{2}$ are the usual end products of sugar fermentation by microorganisms whereas methanol is not, which probably explains the evolution of the use of ethanol by forest insects. Moeck (1970) found methanol to be a minor constituent and ethanol a major constituent of extracts from Douglas fir sapwood attractive to $T$. lineatum.

Various tree monoterpenes (e.g. $\alpha$-pinene, myrcene, terpinolene, $\beta$-pinene) (Fig. 5.4) and turpentine are also attractive to a large number of bark beetle species (Byers et al., 1985; Byers 1992a; Phillips et al., 1988; Schroeder, 1988; Chénier and Philogène, 1989; Schroeder and Lindelöw, 1989; Miller and Borden, 1990; Phillips, 1990; Hobson et al., 1993). Synergism between ethanol and various monoterpenes (or turpentine) is also of widespread occurrence (Nijholt and Schönherr, 1976; Kohnle, 1985; Vité et al., 1986; Phillips et al., 1988; Volz, 1988; Schroeder, 1988; Chénier and Philogène, 1989; Schroeder and Lindelöw, 1989; Phillips, 1990). These compounds are not only important for primary attraction to plants, but also may play a role in enhancing the bark beetles' response to aggregation pheromone (Bedard et al., 1969, 1970; Pitman et al., 1975; McLean and Borden, 1977; Borden et al., 1980, 1981; Paiva and Kiesel, 1985; Byers et al., 1988; Miller and Borden, 1990). Host-tree compounds, ethanol and monoterpenes, elicited increased entering rates of bark beetles $T$. lineatum and $P$. chalcographus, respectively, into pipe traps baited with aggregation pheromone (Vité and Bakke, 1979; Bakke, 1983; Byers et al., 1988). $\beta$ Phellandrene (Fig. 5.4) is slightly attractive alone to $I$. pini and enhances response to pheromone (Miller and Borden, 1990), and so this monoterpene might induce entering of holes.

In most of the above studies, the discovery of host compounds attractive to bark beetles has been by the comparative approach (similar species are known to be attracted) or by surmising that identified chemicals in the host would be attractive. Thus, most studies are incomplete because of the possibility that there are still undiscovered chemicals important for attraction to the host. Byers et al. (1985) used the subtractive-combination bioassay and fractionation method (Byers, 1992c) to identify rigorously the host volatiles responsible for aggregation of $T$. piniperda. A combination of (-)-(S)- $\alpha$-pinene, $(+)-(R)-\alpha$-pinene, (+)-3carene, and terpinolene, or each alone, was effective in attracting both sexes (Fig. 5.4). During the isolation study, designed for detection of synergistic pheromone components, no evidence was found for beetle-produced compounds being attractive, in contrast to most bark beetles that aggregate en masse on hosts (Byers, 1989b). Byers et al. (1985) quantified the release rates of $\alpha$-pinene, terpinolene and 3-carene from a freshly cut $\log$ of Scots pine $(28 \mathrm{~cm} \times 13 \mathrm{~cm}$ diameter) and found them each to be about $15 \mathrm{mg} /$ day. Release of comparable amounts in the field competed favorably with a host $\log$ in attracting $T$. piniperda. They theorized that the attraction to monoterpenes functioned in the beetle's selection of both host species (other common tree species have less monoterpenes) 
and recognition of the host's susceptibility (storm-damaged trees are unable to resist attack and have resinous wounds that release monoterpenes).

In the isolation of host volatiles attractive to $T$, piniperda, a gas-chromatographic adsorbent (Porapak $Q$ ), widely used for trapping insect pheromones, was used to collect headspace air from the infested pine logs. Unfortunately, Porapak $Q$ will not retain ethanol molecules due to their small size. Thus ethanol could be a constituent of the attractive host odor. Vité et al. (1986) presented evidence that ethanol enhanced the attraction of $T$. piniperda to $\alpha$-pinene and terpinolene (identified above) by about eightfold, but these results are difficult to confirm since the chemical release rates were not given. They proposed that ethanol would be released from diseased trees and thus indicate their suitability to $T$. piniperda. Ethanol is attractive when released on healthy trees since $T$. piniperda were caught in ethanol-baited traps on trees, and these beetles also attacked trees baited with ethanol (Schroeder and Eidmann, 1987; Byers, 1992a). However, the attraction to ethanol in traps away from trees is weak or negligible, while monoterpenes in these traps are attractive (Schroeder, 1988; Schroeder and Lindelöw, 1989; Byers, 1992a).

Ethanol, in fact, sometimes reduces response to attractive baits. Klimetzek et al. (1986) tested different release rates of ethanol (24 to $125 \mathrm{mg} /$ day) with an unreported release rate of $\alpha$-pinene and terpinolene and found that the higher releases of ethanol inhibited attraction of $T$. piniperda. However, a control with ethanol alone, or terpenes alone, was not reported. Schroeder (1988) increased the release of ethanol in five dosages over an even wider range from 0 to $50 \mathrm{~g} /$ day in combination with a $240 \mathrm{mg} /$ day release of $\alpha$-pinene. In this case, the attraction of $T$. piniperda declined linearly with the logarithm of ethanol release, in conflict with the theory of Vité et al. (1986) that ethanol was synergistic with monoterpenes.

Schroeder and Lindelöw (1989) provided the first evidence that could integrate the disparate results. They found that a high release of $\alpha$-pinene was most attractive to beetles and that ethanol releases alone from 0 to $3 \mathrm{~g} /$ day were barely attractive. At a low release rate of $\alpha$-pinene $(2.4$ or $22 \mathrm{mg} /$ day) and thus low attraction, the lower releases of ethanol from 0 to $3 \mathrm{~g} /$ day had a synergistic effect with $\alpha$-pinene in attracting beetles (Schroeder and Lindelöw, 1989). Their results are supported by Byers (1992a); i.e., a weak enhancement of attraction by ethanol at low releases of the blend of three host monoterpenes, but no observable effect of ethanol on the greater attraction to higher releases of monoterpenes.

Ethanol released at even higher rates, $120 \mathrm{mg} /$ day (Klimetzek et al., 1986) or $50 \mathrm{~g} /$ day (Schroeder, 1988), inhibits the response of $T$. piniperda to monoterpenes. Therefore, the beetle could find diseased, but physically uninjured, trees by a weak response to a synergism between low monoterpene release rates and moderate ethanol rates - the hypothesis of Vité et al. (1986). These trees would be tested occasionally by beetles, and if low in resistance this would permit 
beetles to continue feeding. Resinosis and monoterpene release would elicit increased numbers joining in a mass-attack. Injured trees with wound oleoresin, and trees under attack with pitch tubes, would have a higher monoterpene release and attract the greatest numbers of beetles, according to Byers et al. (1985). Trees with high ethanol release rates would indicate a tree in advanced decay and unsuitable for reproduction, and thus to be avoided, as theorized by Klimetzek et al. (1986). High monoterpene releases from trees (freshly wounded and not dead) would not naturally coincide with high ethanol release rates (presumably during decay after death). In addition, other compounds such as verbenone from decaying hosts would inhibit response to monoterpenes from unsuitable hosts (discussed in the next section). These studies emphasize the need for releasing semiochemicals at precise rates during tests in the field. In addition, measurements of the natural release rates of ethanol and monoterpenes from various host and nonhost substrates are necessary for further understanding of bark beetle chemical ecology.

\subsection{Avoidance of Unsuitable Host Trees and Nonhosts}

Host-plant suitability in insects has been reviewed by Scriber (1984). A host plant's suitability to bark beetles varies with its nutritional quality and composition of anti-insect toxins. Nonhost trees are probably less nutritional, and the beetle in most cases would not be adapted to detoxifying some of the nonhost toxins that have evolved for use against other herbivorous insects. A beetle would save much time and energy if it can discriminate the host from the nonhost and determine the suitability of a host by olfactory means without the need to land. Sometimes host and nonhost trees are in virtual contact and the beetle could land by mistake on the nonhost; however, short-range olfactory cues might indicate the inappropriateness of the bark substrate. If the beetle still could not decide, boring a short distance into the nonhost might reveal the lack of feeding stimulants or the presence of deterrents so that the beetle would leave.

According to studies in the previous section, bark beetles find their host tree by attraction to host volatiles or after random landing and probing. However, it is becoming increasingly apparent that many beetles avoid nonhost trees due to specific odors. It is inherently more difficult to isolate repellents and inhibitors used in avoidance behavior than to isolate attractants since tests of avoidance require one to first isolate the attractive host odors and then present these with and without the possibly inhibitory nonhost odors. Several studies indicate that at least some species of bark beetle avoid nonhost volatiles during their search for host trees. The attraction of both $T$. piniperda and $H$. palliatus to ethanol (1-6 g/day) was reduced by odors from cut logs of nonhost trees, birch, Betula pendula, and aspen, Populus tremula (Schroeder, 1992). In future experiments, host logs (or monoterpenes and ethanol) should be tested instead of ethanol alone to simulate the host tree. Dickens et al. (1992) reduced the attraction response 
of D. frontalis, I. grandicollis, and $I$. avulsus to aggregation pheromone by release of the green-leaf volatiles, 1-hexanol and hexanal. T. domesticum colonizes wood of deciduous trees (e.g. Fagus sylvatica, Quercus spp., Betula spp.) and is known to be attracted to ethanol (Magema et al., 1982; Paiva and Kiesel, 1985). Conifer monoterpenes of Scots pine and verbenone (from decaying conifers) reduced response of this bark beetle to ethanol (Byers, 1992a) and would provide a mechanism for avoiding nonhosts and unsuitable colonization areas. This also is valid for the hardwood-breeding Anisandrus dispar (Schroeder and Lindelöw, 1989).

In addition to their ability of discriminating the host from among nonhost trees, flying beetles are capable of determining the suitability of their host. Verbenone is found in relatively large amounts $(\mu \mathrm{g})$ in male hindguts of several pest bark beetles of North America, D. frontalis, D. brevicomis, D. ponderosae, and D. pseudotsugae (Renwick and Vité, 1968; Rudinsky et al., 1974; Byers et al., 1984; Pierce et al., 1987), but in low amounts (ng) in T. piniperda (Lanne et al., 1987), or essentially absent in $I$. paraconfusus, $I$. typographus, and $P$. chalcographus (Byers, 1983b; Birgersson et al., 1984, 1990). Verbenone inhibits the attraction of these beetles to their respective aggregation pheromones (Renwick and Vité, 1969, 1970; Byers and Wood, 1980; Bakke, 1981; Byers et al., 1989c; Byers, 1993a). Some microorganisms isolated from bark beetles or their gallery walls may convert $\alpha$-pinene to cis- and trans-verbenol (Bacillus cereus) (Brand et al., 1975), or trans-verbenol to verbenone (various yeasts) (Leufvén et al., 1984). A fungal culture isolated from the mycangium of $D$. frontalis was able to convert trans-verbenol to verbenone, and it was proposed that this process may account for termination of attack (Brand et al., 1976). Verbenone is increasingly released from aging logs of spruce and pine colonized by bark beetles, $I$. typographus (Birgersson and Bergström, 1989) and T. piniperda (Byers et al., $1989 \mathrm{c})$, possibly due to the activity of microorganisms.

Byers $(1989 \mathrm{a}, 1989 \mathrm{~b})$ speculated that if verbenone is a consistent signal of microbial activity in decaying hosts, then a bark beetle species may have evolved an avoidance to this compound (a kairomone) in order to avoid unsuitable hosts. This species then could have evolved to produce verbenone as a pheromone that reduced intraspecific competition, since the avoidance response was already existent. Other bark beetle species might then evolve to avoid species that produced verbenone (as an allomone), and so avoid interspecific competition. Sympatric species on the same host might coevolve response to and/or production of verbenone since the chemical could serve as a signal for several types of beneficial information (kairomone, pheromone, and allomone). Verbenone does not always inhibit bark beetles, for example, $H$. palliatus feeds in unhealthy or dying Scots pines that probably are releasing verbenone (Byers et al., 1989c), and the beetle's attraction to ethanol was not inhibited by verbenone (Byers, 1992a). Although both conifers and deciduous trees in a state of decay release ethanol that is attractive to $T$. domesticum, this beetle chooses only deciduous 
trees as hosts. This may occur because $T$. domesticum has evolved to avoid decadent nonhost conifers by avoiding verbenone since deciduous trees probably do not release this compound (deciduous trees lack likely monoterpene precursors of verbenone such as $\alpha$-pinene) (Byers, 1992a).

In the case of conifer bark beetles, verbenone is increasingly implicated as a general sign of host unsuitability (due to microbial decay or competition with bark beetles). Therefore, it is paradoxical that conifers have not evolved the capacity of converting $\alpha$-pinene, which they have in abundance, to verbenone in order to become repellent to bark beetles and thereby increase resistance.

\section{Feeding Stimulants and Deterrents}

Presumably, the beetle must not only determine that the bark underneath is the proper host and is suitable for reproduction, but it must also judge potential competition by whether nearby areas have bark beetles beginning their attacks. Many species of bark beetle bore their entrance holes in a spaced or uniform pattern, indicating the beetles are territorial in order to avoid competition (Byers, $1984,1992 \mathrm{~b}$ ). In some cases the beetle will bore through the outer bark, regardless of the host, until it encounters the phloem. For example, I. paraconfusus will bore through the outer bark of the nonhost white fir, Abies concolor, as readily as through bark of the host ponderosa pine. However, the beetle only bores about $1 \mathrm{~mm}$ in white fir phloem and then leaves (Elkinton and Wood, 1980). At this time gustatory stimulants and deterrents (also possibly olfactory cues) are balanced in a decision whether to continue feeding and excavating the gallery. The beetle probably can determine whether the host tissue is of good quality in terms of nutritional and moisture factors (Webb and Franklin, 1978). The phloem of ponderosa pine, sugar pine ( $P$. lambertiana), Douglas fir (Pseudotsuga menziesii), red fir (Abies magnifica), and several other conifers contain about equal amounts of glucose, fructose and sucrose (Smith and Zavarin, 1960). Bark beetles have been induced to feed or lay eggs on several diets, but the most successful contain some percentage of host (usually phloem) tissue (Jones and Brindley, 1970; Richeson et al., 1970; Whitney and Spanier, 1982; Conn et al., 1984; Byers and Wood, 1981a), indicating the presence of feeding or ovipositional stimulants. Sucrose was found in preliminary experiments to increase feeding by $I$. paraconfusus in powdered cellulose diets (Byers and Wood, 1981a).

Few studies have attempted to isolate feeding stimulants in conifer-feeding bark beetles, and none have isolated specific compounds. Elkinton et al. (1981) extracted ponderosa pine phloem successively with diethyl ether (partitioned with water), water, and then methanol, and added these extracts to powdered cellulose diets. I. paraconfusus beetles were then given a choice between a control diet and a diet with extract. The diet with the ether extract did not cause beetles to 
remain longer, but did cause more feeding but no preferential boring. The water partition of the ether extract only caused beetles to remain longer. The water extract elicited more boring and feeding, while the methanol extract was inactive since feeding stimulants had already been extracted by the ether and water treatments. These results indicate that several compounds function in gustatory preferences. Solvent (methanol-water-benzene) extracts of lodgepole pine bark (Pinus contorta) were absorbed by tissue paper and shown to induce feeding by $D$. ponderosae (Raffa and Berryman, 1982b). The benzene fraction induced biting but not feeding while the polar fraction (water-methanol) caused continued feeding. Differences in feeding preferences for bark extracts were large between trees, but these differences could not be attributed to amounts of 13 monoterpenes as determined by gas chromatography (GC). Also, extracts of trees judged resistant, because beetles that had been forced to attack in cages either refused or discontinued attack, were as stimulatory to feeding beetles as those from susceptible trees. In contrast, Hynum and Berryman (1980) found greater feeding preferences for extracts of bark of susceptible than of resistant lodgepole pine. However, the susceptible trees had been killed by the beetles before solvent extraction, which might have allowed microorganisms to produce additional feeding stimulants. White (1981) also found differences in gustatory deterrent and stimulatory properties of bark extracts from different trees of loblolly pine, $P$. taeda.

In beetles of deciduous trees, most work on feeding stimulants and deterrents involves the elm bark beetle, $S$. multistriatus. Vanillin and syringaldehyde are short-range attractants inducing feeding in $S$. multistriatus (Meyer and Norris, 1967b). Feeding stimulants were isolated from the bark of American elm, Ulmus americana, of which one was partially identified as a pentacyclic triterpene (Baker and Norris, 1967). Later some lignin intermediates and phenolics were indicated (Meyer and Norris, 1974). Doskotch et al. (1973) succeeded in identifying another feeding stimulant in elm bark as a catechin xyloside. A tritiated catechol feeding stimulant was shown to penetrate the gustatory receptor of $S$. multistriatus (Borg and Norris, 1971). Scolytus rugulosus are stimulated to feed in fruit trees by several phenolic compounds (Chararas et al., 1982).

$S$. multistriatus was induced to feed on sucrose pith disks when volatiles from benzene extracts of bark of nonhost trees (Eastern cottonwood, Populus deltoides, and yellow buckeye, Aesculus octandra) were placed $7 \mathrm{~mm}$ away (Baker and Norris, 1968). However, these nonhost trees were not fed upon since they contained nonvolatile feeding deterrents as shown by lowered feeding on a mixture of host and nonhost extracts compared to host extracts. $S$. multistriatus beetles do not attack the nonhost hickory, $C$. ovata, due to the presence of juglone (5-hydroxy-1,4-napthoquinone), a feeding deterrent (Gilbert et al., 1967). Elm tree tissue infected by the fungus $P$ homopsis oblonga is avoided by $S$. multistriatus due to several feeding deterrents of complex structure, e.g., oblongolide (isomer of dimethylnapthofuranone), a norsesquiterpene lactone, two tiglic esters of 5,6- 
dihydro-5-hydroxy-2-pyrones, nectriapyrone, 4-hydroxyphenylethanol, 5-methylmellein as well as acids of 2-furoic, orsellinic, 3-nitropropanoic, and mellein5-carboxylic (Begley and Grove, 1985; Claydon et al., 1985).

Diterpene acids (e.g., abietic, levopimaric, neoabietic, and palustric acids) have been isolated from ponderosa pine oleoresin (Anderson et al., 1969; Himejima et al., 1992) and these are known from other conifers to be antifeedants against aphids and sawflies (Wagner et al., 1983; Schuh and Benjamin, 1984; Rose et al., 1981), but have not been tested on bark beetles. Tannins, phenolics and terpenoids that can inhibit feeding or digestion in other insects (Berenbaum and Isman, 1989) could also affect bark beetles, but again there are no reports. Ponderosa pine bark extracted first with ether yields behenic and lignoceric acids, fatty alcohols, resin acids, and flavonols (quercetin and myricetin, pinoquercetin, pinomyricetin and dihydroquercetin), a subsequent acetone extract contains tannins and phlobaphenes, while a hot-water extract has tannin (6-11\% dry weight of bark) and carbohydrates (Anderson, 1962; Anderson et al., 1969). Many of these compounds are found only in the outer bark and although they may be important in deterring nonhost bark beetles, at least the host-adapted $I$. paraconfusus does not eat the outer bark (Elkinton and Wood, 1980).

\section{Plant Compounds and Resin in Resistance Mechanisms}

Resistance of pines to bark beetle attacks has long been attributed to the amount of resin exudation and formation of pitch tubes (Webb, 1906). It is obvious that oleoresin acts to entrap and impede the excavation efforts of bark beetles. Dead beetles can often be seen in crystallized resin of pitch tubes. However, $D$. brevicomis and other aggressive bark beetles have a great ability to survive the toxic monoterpenes and suffocating mucilage and may struggle for hours in copious resin flows (D. frontalis) (Hodges et al., 1979). I have observed $D$. brevicomis beetles completely covered with resin while attempting to clear the entrance tunnel (Fig. 5.7), and it appears that breaths of air are taken by slightly lifting the elytra that protect the spiracle openings on the dorsal side of the abdomen; later these beetles entered the tree and made galleries (Byers et al., 1984). Bark beetles cannot attack all hosts since in experiments where three female $D$. ponderosae were caged on each of 79 trees, only 43 trees were attacked, and of these just 15 were successful so that aggregations resulted (Raffa and Berryman, 1979).

Oleoresin may provide resistance to trees due to chemical toxicity to the beetle and associated microorganisms or to physical impedance and entrapment (Hodges et al., 1985). Oleoresin and the monoterpenes therein are repellent to bark beetles in concentrated amounts (Struble, 1957; Pitman et al., 1966; Berryman and Ashraf, 1970; Bordasch and Berryman, 1977). Drought and poor water balance lowers the resistance of conifers (Hodges and Lorio, 1975; Hodges et al., 1979) 


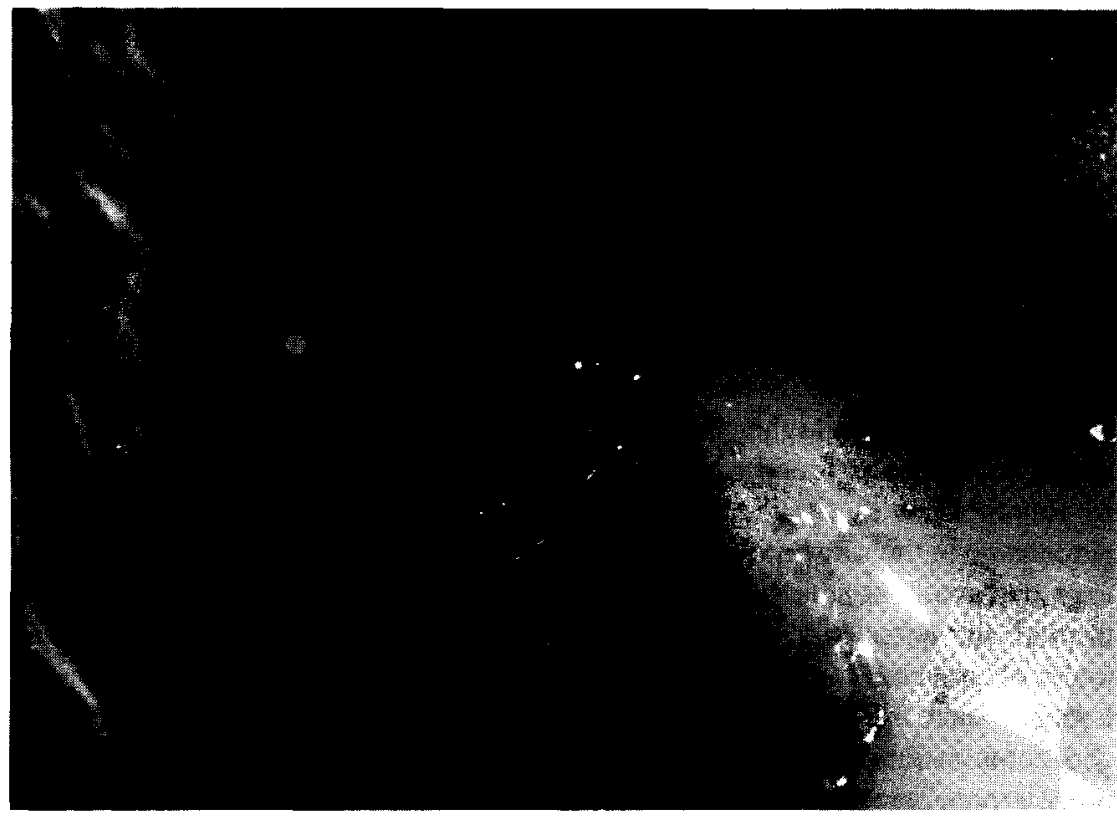

Figure 5.7. Westem pine beetles, Dendroctonus brevicomis, "swimming" in oleoresin exuding from a pitch tube on the bark of ponderosa pine. The beetle (in center of photo) and its mate undermeath were observed to burrow down through the viscous liquid into the entrance of the gallery (directly under and to right of beetles) for up to several minutes before returning and shoving out more resin. The resin is slightly toxic and may exhaust the beetles; it also may eventually crystallize to entrap them.

probably by lowering the turgidity of resin duct cells, which lowers the oleoresin exudation pressure (OEP). A correlation between higher OEP and greater resistance of ponderosa pine to attack by $D$. brevicomis and $I$. paraconfusus has been reported (Vité, 1961; Wood and Vité, 1961; Wood, 1962; Brown et al., 1987). Hodges et al. (1979) found that in more resistant pines their resin was slower to crystalize ( $P$. elliotii) or had a higher resin flow ( $P$. palustris) compared to more susceptible trees ( $P$. taeda and $P$. echinata) colonized by $D$. frontalis. Cook and Hain (1987) also found that susceptible shortleaf pines, $P$. echinata, had a lower resin flow than resistant trees. However, Raffa and Berryman (1982c) found no relationship between resistance and the rate of resin flow or crystallization. Also, Schroeder (1990) found no difference in resin flow between resistant and susceptible Scots pine, $P$. sylvestris, fed on by $T$. piniperda. Western larch, Larix occidentalis, had no OEP but the trees with higher content of 3-carene in the resin were attacked less by $D$. pseudotsugae (Reed et al., 1986).

Another factor that might be more important for resistance could be the toxicity of compounds within the resin. Smith $(1961,1965 a, 1965 b)$ exposed beetles of 
several Dendroctonus species to resin vapors from host and nonhost pines and found beetles were able to tolerate vapors of their host better than nonhosts. In an attempt to determine which components of the resin vapor were toxic to bark beetles, various conifer monoterpenes were presented alone at vapor saturation to $D$. brevicomis held in a glass chamber (Smith, 1965b). The most toxic monoterpene was limonene, followed by $(+)-3$-carene, myrcene, $(-)-\beta$-pinene and then $\alpha$-pinene. In another study, Smith (1965a) found that $\mathrm{n}$-heptane, a major constituent of Jeffrey pine $(P$. jeffreyi), was quite toxic to $D$. ponderosae which does not feed in this tree, whereas $D$. jeffreyi beetles showed little mortality in saturated vapors. However, the monoterpenes when presented alone at saturation were from 40 to 80 times higher in concentration than in the natural atmosphere of a beetle's gallery, as found empirically by GC headspace analysis and explained by Raoult's law that states the vapor pressure of a compound is due to its mole percentage in the substrate/solvent mixture (Byers, 1981b). Most of these species may also avoid monoterpene vapors temporarily by breathing at ventilation holes through the outer bark. Thus, Smith's conclusion that monoterpenes are toxic under natural conditions is dubious, but his results may still indicate these monoterpenes increase mortality of bark beetles over longer periods during feeding and colonization. Raffa et al. (1985) exposed Scolytus ventralis to the above monoterpene vapors and also found limonene the most toxic, but myrcene, $\alpha$ pinene, $\beta$-pinene, and 3-carene, in that order also caused significant mortality.

Differences in monoterpene composition within a tree are slight, even from year to year (Smith, 1964; Byers and Birgersson, 1990). Differences in monoterpene ratios can be large between trees of one area, almost as large as differences over wide geographic regions (Smith, 1964, 1966, 1967, 1969). The oleoresins of 88 trees under attack by $D$. brevicomis and subsequently killed were compared to those from 202 living trees, and the living trees had a higher content of myrcene and limonene in their resins (Smith, 1966). This correlation supports the theory that limonene is important in host resistance.

Sturgeon (1979) theorized that $D$. brevicomis is a selective force in the evolution of ponderosa pine, $P$. ponderosa, and that therefore areas of recent outbreaks might have selected trees with a higher titer of limonene (since these trees would be more resistant). Eight populations of trees, a total of 617 trees, were sampled for monoterpenes and analyzed by principal component multivariate statistics. The average proportions of myrcene and $\alpha$-pinene in resins from the eight populations ranged the least $(10.0-15.2 \%$ and $4.5-9.2 \%$, respectively), while the other monoterpenes varied more (3-carene, 23.6-60.4\%; $\beta$-pinene, $13-35 \%$; limonene, $6.1-18.7 \%$ ). The populations were separated by the Cascade Range in northern California and southern Oregon into two regions. The west side had higher proportions of myrcene, $\beta$-pinene, and limonene. The proportion of limonene in resin from three populations considered to have been historically under heavy bark beetle predation was higher than in populations not considered to have such a history (Sturgeon, 1979). The problem with these findings is that a 
correlation is made between rather accurate monoterpene results and rather poor knowledge of former predation pressure by $D$. brevicomis, or for that matter other bark beetle species in each of the areas.

Sturgeon (1979) concluded that $D$. brevicomis beetles (and others) may exert a frequency-dependent selection pressure on chemically polymorphic populations of ponderosa pine. Thus after beetles have colonized most of the low limonene and less resistant trees during an epidemic, the beetle population would either (1) Die out or disperse to areas that had more chemically susceptible trees; or (2) evolve a tolerance to limonene. The second possibility was considered less likely because of the large variation in monoterpene composition among trees that would make it improbable that selection of beetles would occur that were capable of detoxifying all of these compounds. However, bark beetles, including I. paraconfusus and $D$. brevicomis, already must be able to detoxify all of these compounds since they survive exposure to monoterpene vapors in part by converting them to oxygenated products that are more soluble and readily excreted (Hughes 1973, 1974; Byers, 1981a, 1981b, 1982, 1983a, 1983b; Pierce et al., 1987). Another hypothesis is that limonene might not always be the most toxic to a bark beetle population, but rather those monoterpenes that the population is not well adapted to (since they occur infrequently) are the most toxic. In this regard, lodgepole pines in some regions of California have very high titers of limonene (Byers and Birgersson, 1990), yet they are readily attacked and killed by $D$. ponderosae.

Gollob (1980) measured the monoterpene content of resin from unattacked loblolly pines, $P$. taeda. Two apparently resistant pines that had survived attack by $D$. frontalis in an epidemic area had a much higher content of myrcene compared to other trees that were killed by the beetle and had low or trace amounts of myrcene. However, no consistent differences in monoterpene composition of Douglas fir, $P$. menziesii var. glauca, resin were found between trees that had resisted attack by $D$. pseudotsugae and trees that had succumbed (Hanover and Furniss, 1966). Similarly, Raffa and Berryman (1982c) found no relationship between monoterpene composition and degree of resistance of lodgepole pines, $P$. contorta var. Latifolia, to $D$. ponderosae. Hodges et al. (1979) also did not find differences in monoterpene or resin acid composition which could account for differences in resistance among four pine species to attack by $D$. frontalis.

In addition to the wound or primary resin production, conifers have a secondary or hypersensitive response to attack (Reid et al., 1967; Berryman 1969, 1972; Berryman and Ashraf, 1970; Raffa and Berryman, 1982a, 1983; Christiansen et al., 1987). The tree responds by isolating the invading insect or fungus within a lesion of dead cells and secondary resin by autolysis of cells and formation of traumatic resin containing higher concentrations of monoterpenes and phenolics (Reid et al., 1967; Berryman, 1969, 1972; Shrimpton, 1973; Wong and Berryman, 1977; Wright et al., 1979; Raffa and Berryman, 1982a, 1982c, 1983; Hain et al., 1983; Croteau et al., 1987). 
Croteau et al. (1987) identified elevated levels of monoterpenes and diterpene resin acids in stems of lodgepole pine inoculated with blue-stain fungus Ceratocystis clavigera, resulting in induced lesions and secondary resin production. The inoculated stems contained about three times more of the monoterpenes $\alpha$ pinene, $\beta$-pinene, 3-carene, and $\beta$-phellandrene, but less limonene. De novo resin synthesis was indicated in the infected tissue since radiolabeled sucrose was incorporated up to 20 times faster into monoterpenes and up to 10 times faster into diterpene resin acids. Chitosan, a fungal wall fragment, induced monoterpene biosynthesis and increased levels of terpene cyclase enzyme which converted radiolabeled terpene precursors (geranyl pyrophosphate and farnesyl pyrophosphate) to labeled monoterpenes and sesquiterpene olefins, respectively (Croteau et al., 1987). Nearly all $S$. ventralis females leave their entrance holes in grand fir, Abies grandis, when hypersensitive reactions are evident (Berryman and Ashraf, 1970). Shorter egg galleries are made or fewer eggs are laid by females in lesions (Berryman and Ashraf, 1970; Paine and Stephen, 1988).

The hypersensitive wound reaction not only affects bark beetles directly, but inhibits symbiotic microorganisms from growing and killing the tree. Blue-stain and other symbiotic fungi are surrounded and isolated in the lesions (Wong and Berryman, 1977; Stephen and Paine, 1985; Paine and Stephen, 1987, 1988). Sometimes, phytopathogenic fungi (e.g., Ceratocystis minor var. barrasii) that are carried in the beetle's mycangium ( $D$. frontalis) do not stimulate the hypersensitive response and thus spread to kill the tree (Paine and Stephen, 1987). Possibly the fungi secrete compounds, such as water-soluble glycans, that inhibit the plant's defensive hypersensitivity—as in potatoes (Doke and Tomiyama, 1980). Cobb et al. (1968) cultured four species of Ceratocystis fungi associated with bark beetles (species: ips, minor, schrenkiana, and pilifera) as well as the root pathogen fungus, Fomes annosus, during exposure to saturated atmospheres of oleoresin or monoterpenes of the host ponderosa pine. They found that all fungal species were inhibited in growth by oleoresin except $C$. ips, while all the monoterpenes (the five discussed above plus $\beta$-phellandrene and camphene) as well as undecane (present in Jeffrey pines) inhibited growth of the fungal species. Camphene and undecane were the least toxic, $\alpha$-pinene was intermediate, while $\beta$ pinene, $\beta$-phellandrene, and 3-carene were more toxic, with myrcene and limonene the most toxic. However, the most toxic of all compounds tested was nheptane (also the most volatile), a major constituent of digger pine, $P$. sabiniana (Mirov, 1961). When the monoterpenes were incorporated into the culture medium as well as in the vapor phase, myrcene and $\beta$-phellandrene appeared the most toxic to most species, but all of the monoterpenes and undecane reduced fungal growth (Cobb et al., 1968). They also indicated that (+)- $\alpha$-pinene was more inhibitory than the $(S)$-enantiomer. The growth inhibition by monoterpenes was proposed to allow the tree time to synthesize phenols (Shain, 1967) such as pinosylvin (Anderson, 1962) that would kill the fungi (Cobb et al., 1968).

Bridges (1987) tested $\alpha$-pinene and $\beta$-pinene on two mycangial fungi of $D$. 
frontalis and the blue-stain fungi, $C$. minor. $\beta$-pinene inhibited growth of $C$. minor, both monoterpenes inhibited one mycangial fungi while the other fungus was stimulated. A phenylpropanoid, 4-allylanisole, from $P$. taeda resin inhibited growth of all fungi tested. Himejima et al. (1992) steam-distilled ponderosa pine oleoresin into a distillate of monoterpenes and sesquiterpenes and a residue of four diterpene acids. The individual monoterpenes of the distillate were not inhibitory to growth of several gram-positive bacteria (at $800 \mu \mathrm{g} / \mathrm{ml}$ ) but did inhibit two species of fungi. Longifolene, a sesquiterpene, inhibited the grampositive but not the gram-negative bacteria. Other species of common mold fungi were not affected by the monoterpenes, but the diterpene acid, abietic acid, was effective against three species of gram-positive bacteria. Although these species of microorganisms are not those associated with bark beetles, the results indicate that oleoresin constituents may be important as a general defense against microorganisms.

The carbon balance of a tree is the relative level of photosynthate available for growth, maintenance, and biosynthesis of defensive compounds. Christiansen et al. (1987) have reasoned that too little moisture (drought), insect defoliation, and root pathogens will reduce the amounts of carbon available for biosynthesis of primary and secondary resin. Mild drought may actually increase resistance of trees by lowering growth rates and shifting the use of photosynthate to the biosynthesis of defensive chemicals, while extended drought will increase the probability of bark beetle outbreaks due to the depleted carbon reserves (Christiansen et al., 1987). A similar theory of tree resistance and attack by southern pine beetles was developed by Lorio (1986).

\section{Plant Compounds as Precursors of Semiochemicals}

Bark beetle pheromones used in aggregation and for avoidance of competition consist of many varied structures (Fig. 5.5). Many of the same pheromonal compounds are used by species in the same genus, such as ipsenol, ipsdienol, and cis-verbenol in the genus Ips, or exo-brevicomin, frontalin, trans-verbenol and verbenone in the genus Dendroctonus [see Borden (1982), Birch (1984), and Byers (1989b)]. Some compounds such as cis- and trans-verbenol may be found in Ips (Scolytinae) as well as Dendroctonus and Tomicus (Hylesininae). However, cis-verbenol has so far only been proven as an aggregation pheromone component for species in the subfamily Scolytinae, whereas trans-verbenol has semiochemical activity only in the subfamily Hylesininae (Fig. 5.5). Verbenone, although inhibiting attraction response of most bark beetle species tested so far, is produced in significant amounts only by species of Hylesininae (primarily or exclusively by males).

The base structure of ipsenol, ipsdienol, and $E$-myrcenol resembles the plant monoterpene, myrcene; likewise, cis- and trans-verbenol as well as verbenone 
resemble $\alpha$-pinene (Figs. 5.4 and 5.5). These structural similarities support the hypothesis, considered next, that in many cases bark beetles use plant compounds as precursors for their pheromone components. This hypothesis also seems logical in that a beetle would save energy by reducing the biosynthetic costs in the production of pheromones.

\subsection{Precursors of Aggregation Pheromone Components}

Aggregation pheromone components were first identified in bark beetles from male Ips paraconfusus as a synergistic blend of $(S)-(-)$-ipsenol, $(S)$-(+)-ipsdienol, and (4S)-cis-verbenol (Silverstein et al. 1966, 1967; Wood et al. 1968). Several other Ips species were soon discovered to produce and respond to various blends of these compounds (Vité et al., 1972). The similarity of chemical structure between a major host monoterpene, myrcene, and ipsenol and ipsdienol (Figs. 5.4 and 5.5) led Hughes (1974) to propose that myrcene was a precursor of these pheromone components in Ips. Exposure of males of $I$. paraconfusus to myrcene vapor resulted in their production of compounds with GC retention times identical to ipsenol and ipsdienol (Hughes, 1974). Byers et al. (1979) confirmed these identifications using gas chromatography and mass spectrometry (GC-MS) and behavioral assays, and reported the male-specific quantitative relationships between precursor vapor concentration and pheromone products. Hendry et al. (1980) radiolabeled myrcene and proved it could be directly converted to the pheromone components (Fig. 5.8). Earlier, Hughes (1974) had proposed that ipsdienol was directly converted to ipsenol, since topical application of ipsdienol on males resulted in ipsenol production. This was confirmed by deuterium-labeled ipsdienol $(64 \% d$ ) being converted to labeled ipsenol (25\% d) (Fish et al., 1979). Intermediates such as ipsdienone and ipsenone (Fig. 5.8) also have been suggested in the biosynthetic pathways (Fish et al., 1979; Byers and Birgersson, 1990).

Another host monoterpene, $(-)-\alpha$-pinene, in the vapor phase is converted to (S)-cis-verbenol in both sexes of $I$. paraconfusus (Fig. 5.9) (Renwick et al. 1976), and the relationship between vapor concentration and pheromone component production was quantified (Byers 1981b). The production of $(-)$-cis-verbenol and $(+)$-trans-verbenol in I.typographus and I. amitinus from the (-)- and (+)enantiomers of $\alpha$-pinene was shown to have a similar relationship by Klimetzek and Francke (1980). The ratio of cis-/trans-verbenois produced by I. typographus was consistent with the ratio of enantiomers of $\alpha$-pinene in the host tree, which differed between trees of different regions and genotypes (Klimetzek and Francke, 1980; Lindström et al., 1989).

Based on the above studies, a paradigm was established that $I$. paraconfusus, and probably most other Ips species, use myrcene and (-)- $\alpha$-pinene in their host tree as precursors to ipsenol and ipsdienol or cis-verbenol, respectively. The evolution of host selection behavior by Ips bark beetles could be influenced by the amounts of $\alpha$-pinene and myrcene in the tree (Elkinton et al. 1980). The 
Myrcene<smiles>C=CC(=C)CCC(=C)C</smiles><smiles>C=CC(=C)CC(O)C=C(C)C</smiles>

\section{(S)-(+)-Ipsdienol *}

(S)-(-)-Ipsenol *

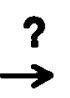<smiles>C=CC(=C)C[C@H](O)C=C(C)C</smiles>

(R)-(-)-Ipsdienol (enzyme bound?)

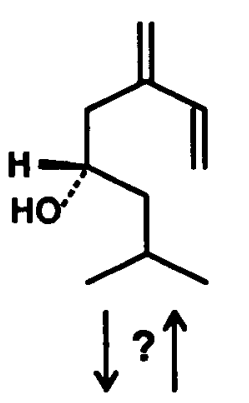<smiles>C=CC(=C)CC(=O)CC(C)C</smiles>

Ipsenone

Figure 5.8. Proposed scheme for the conversion of the host-tree compound, myrcene, to the pheromone components $(S)-(-)$-ipsenol and $(S)-(+)$-ipsdienol in Ips paraconfusus based on radiolabeling experiments and enantiomers found in the male (Silverstein et al., 1966; Wood et al., 1968; Hughes, 1974; Renwick et al., 1976; Byers et al., 1979; Fish et al., 1979; Hendry et al., 1980; Byers, 1981; Byers and Wood, 1981). Conversion arrows with question marks have not been proven. $(R)$-(-)-ipsdienol does not accumulate in the hindgut but may occur as an enzyme-bound intermediate. However, the myrcene used in the biosynthetic pathways does not appear to come directly from the tree since males feeding in four species of pine with different titers of myrcene produced the same amounts of ipsenone, $(S)-(-)$-ipsenol, and $(S)-(+)$-ipsdienol as did males in Pinus sabiniana, which did not contain any detectable myrcene (Byers and Birgersson, 1990).

variation of monoterpenes among trees within a species (Mirov 1961; Smith 1964, 1967) might allow beetles to have evolved preferences for trees that had large amounts of precursor for use in biosynthesis of aggregation pheromone components. A second hypothesis is that tree genotypes may have evolved through natural selection which are lower in pheromone precursor monoterpenes as a means of resistance to bark beetles (Byers, 1989a). It is still not known whether selection pressure by bark beetle predation is severe enough to cause the evolution of trees with lower amounts of $\alpha$-pinene as a means of resistance.

In contrast to the paradigm above, recent studies question the importance of myrcene precursor quantities within the host tree in the coevolution of aggregation 
Tree monoterpene

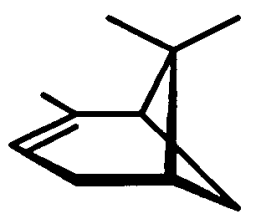

(S)-(-)- $\alpha$-pinene

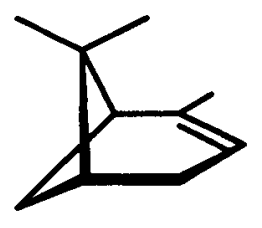

(R)-(+)- $\propto-$ pinene
Ips paraconfusus

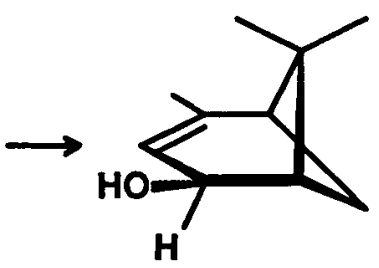

(4S)-(-)-cis-verbenol

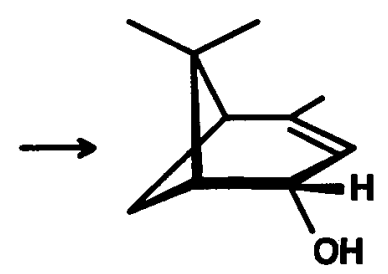

(4S)-(+)-trans-verbenol
D. brevicomis

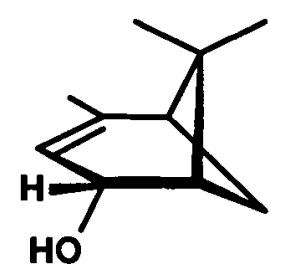

(4R)-(-)-trans-verbenol

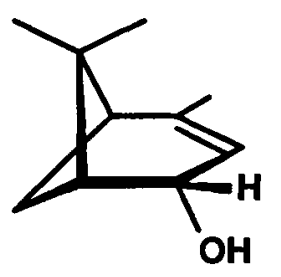

(4S)-(+)-trans-verbenol

Figure 5.9. Stereoselective conversion of the two enantiomers of the host-tree monoterpene, $\alpha$-pinene, to pheromone components (4S)-cis-verbenol in Ips paraconfusus and (4R)-trans-verbenol in D. brevicomis.

pheromone components in Ips paraconfusus. This is because males of $I$. paraconfusus produced almost identical amounts of the pheromone components ipsenol and ipsdienol when feeding in five different host pine species, regardless of the large differences in concentrations of myrcene in these trees (Byers and Birgersson, 1990). In fact, digger pine, $P$. sabiniana, had so little myrcene that it could not be detected by GC-MS, and it was calculated that a beetle would need to eat at least eight times its weight in toxic and repellent oleoresin in order to have any possibility of obtaining the required amounts of myrcene. Apparently in this case the expected energetic advantages of using a precursor from the host that is structurally similar to the pheromone components are outweighed by the need for the beetle to retain control over the ecologically critical pheromone system. The beetle could maintain control by means of either de novo biosynthesis or use of a simpler host precursor found in all potential hosts.

Streptomycin, a 70 S ribosome-active antibiotic, when fed to $I$. paraconfusus inhibited their ability to produce ipsenol and ipsdienol, but the antibiotic had no affect on $\alpha$-pinene conversion to cis-verbenol (Byers and Wood, 1981a; Hunt and Borden, 1989). However, I. paraconfusus reared axenically (without microorganisms) could still produce reduced amounts of ipsenol and ipsdienol (Conn et al., 1984; Hunt and Borden, 1989). Any symbiotic microorganisms involved in pheromone biosynthesis would have to be transovarially transmitted in order 
to survive the axenic rearing methods (Hunt and Borden, 1989). Juvenile hormone is also implicated in pheromone biosynthesis: topical application induces ipsenol and ipsdienol production in $I$. paraconfusus in the absence of external myrcene (Hughes and Renwick, 1977). Other pheromones such as verbenone, exo-brevicomin, and frontalin are found in emerged $D$. brevicomis before they land on the tree (Byers et al., 1984).

Exposure of Ips duplicatus to myrcene vapor causes the beetle to produce small amounts of its pheromone component ipsdienol but not $E$-myrcenol, the other component (Schlyter et al., 1992). Both compounds are expected to be made from myrcene (Pierce et al., 1987). Ivarsson et al. (1993) found that the biosynthesis of both $E$-myrcenol and ipsdienol from mevalonate in $I$. duplicatus could be blocked by the enzyme inhibitor compactin, but the production of cisverbenol from $\alpha$-pinene in $I$. typographus was not affected by the inhibitor. These studies, and those on I. paraconfusus above, indicate that the major pathway in nature for biosynthesis of the pheromone components ipsdienol, ipsenol, and $E$-myrcenol in Ips is de novo from mevalonate.

\subsection{Precursors of Pheromones and Allomones for Avoiding Intra- and Interspecific Competition}

As mentioned in section 2.4, many prevalent bark beetle species in Dendroctonus and Tomicus produce verbenone, which affects behavior in their own species as well as competing species in these genera and others (Ips, Pityogenes) by reducing their response to aggregation pheromone. Exposure of male and female $D$. brevicomis to (+)- and (-)- enantiomers of $\alpha$-pinene for several hours caused them to produce large amounts of $(+)$ - and (-)-trans-verbenol in their hindguts (Fig. 5.9) (Byers, 1983a). However, the biosynthesis of verbenone in these beetles was not affected by exposure to $\alpha$-pinene enantiomers, even though verbenone is structurally similar to $\alpha$-pinene (Figs. 5.4 and 5.5) and is found in males landing on trees (Renwick and Vité, 1968, 1970; Byers et al., 1984). The (-)-enantiomer of trans-verbenol inhibits female $D$. brevicomis from entering holes and may serve as a signal to arriving females that they should avoid areas colonized by conspecifics (Byers, 1983a).

Both verbenone and trans-verbenol are produced by $D$. brevicomis beetles in the greatest amounts early in colonization so it was suggested that they play a role in reducing intraspecific competition (Byers et al., 1984) as well as interspecific competition with I. paraconfusus (Byers and Wood, 1980). However, verbenone (and possibly trans-verbenol) are also produced increasingly in aging logs infested by bark beetles (Birgersson and Bergström, 1989; Byers et al., 1989c). A common bacterium, Bacillus cereus, also isolated from $I$. paraconfusus can make cisand trans-verbenol from $\alpha$-pinene (Brand et al., 1975). Several yeasts from $I$. typographus can interconvert the verbenols, and when grown in a phloem medium they produced the oxygenated monoterpenes $\alpha$-terpineol, borneol, myrtenol, 
terpenene-4-ol, and trans-pinocarveol, compounds also shown to be released increasingly from bark beetle holes with age of attack (Leufvén et al., 1984, 1988; Birgersson and Bergström, 1989). A mycangial fungus grown in culture media converted alcohol products of $\alpha$-pinene to verbenone, the end product (Brand et al., 1976). These microorganisms are introduced by bark beetles during colonization and after buildup may release verbenone, thus signalling to flying beetles that immigrating to these bark substrates would entail competition with established bark beetle colonies.

Myrcene and $\alpha$-pinene may be used as precursors of pheromones and allomones in some species of conifer-feeding bark beetles. D. brevicomis, I. paraconfusus, and I. pini occur sympatrically in California and Oregon and compete for ponderosa pine bark. Myrcene is converted sex-specifically by male $D$. brevicomis to $(+)$-ipsdienol, also a pheromone component of its competitor 1 . paraconfusus (Hughes 1973; Byers, 1982). (+)-Ipsdienol inhibits response of both D. brevicomis and I. pini to their synthetic aggregation pheromones (Birch et al., 1980a; Lanier et al., 1980; Byers, 1982). In Europe, ipsdienol, a pheromone component of $I$. duplicatus could act as an allomone to inhibit response of $I$. typographus (Byers et al., 1990; Schlyter et al., 1992). Mated males of I. typographus produce small amounts of ipsdienol and ipsenol during colonization that might function in avoiding competition (Birgersson et al., 1984; Birgersson and Leufvén, 1988). Although ipsdienol was earlier thought to be an aggregation pheromone component of I. typographus (Bakke et al., 1977), other studies have shown the compound to inhibit attraction of these beetles to cis-verbenol and methyl butenol, the most potent components (Schlyter et al., 1987b, 1087c).

\section{Secondary Plant Compounds and Bark Beetle-Tree Coevolution}

Secondary plant compounds are those chemicals not believed to be necessary for the basic metabolism of plant cells (Whittaker, 1970). Since the compounds occur in some plant families, often of very different lineage, and not in other families, they appear to have evolved independently for the defense against a common enemy such as fungi or insects (Feeny, 1975). Secondary plant compounds include many exotic structures: phenolics, cinnamic acids, coumarins, lactones, quinones, and glycosides of the foregoing, as well as furan and pyranes, anthraquinones, flavonoids, anthocyanin, polymeric phenolics (tannins), monoterpenoids, sesquiterpenoids, di- and triterpenoids, resin acids, steroids, cardiac glycosides, ecdysone analogues, and alkaloids.

Secondary plant compounds important for host finding from long range would necessarily be volatile. Some of the most common volatiles in conifers are the monoterpenes and thus it is not surprising that bark beetles are often attracted to these chemicals even though in high concentrations they are toxic. It could 
be expected that volatile monoterpenes shown to be important for a species in one geographic region might not be attractive to populations of this species in another region, if the trees in the second region have different proportions of the monoterpenes. The monoterpenes do vary in ponderosa pine throughout the western United States (Smith, 1964, 1966, 1967, 1968, 1969). This could explain why different populations of $D$. brevicomis may have responded differently to myrcene or 3-carene as synergists of pheromone components (Bedard et al., 1969, 1970; Pitman, 1969).

Quantities of volatile compounds such as ethanol and verbenone that are released from killed trees later during colonization by beetles and microorganisms are probably not regulated by the tree's genetics. Thus, trees are not under selection pressure from bark beetles because the tree has no control over how the insects use these compounds (as pheromones, allomones or kairomones) to indicate potential competition or decaying, unsuitable host areas. Kairomones, in contrast to pheromones and allomones, are not used in chemical communication, in which both parties, sender and receiver, must gain a benefit (Burghardt, 1970).

Host-plant specificity by insects may be the result of plant-insect coevolution of chemical defenses and interspecific competition. Those insect species that do not adapt to a genetic change in host-plant chemistry during evolution are not able to eat the plant as effectively and thus are at a competitive disadvantage to those species that adapt first. The consequence is that one or a few species now become prevalent (major pests) because of reduced interspecific competition.

Hughes $(1973,1974)$ hypothesized that aggregating pheromones in Dendroctonus and Ips are "waste products from the metabolism of terpenes that have secondarily been utilized as chemical messengers." $D$. ponderosae have an enzyme system that indiscriminately hydroxylates monoterpenes on allylic methyl groups that are $E$ to a methylene or vinyl group as a way of detoxifying monoterpenes (Pierce et al., 1987). The products may also be more easily excreted due to the increased solubility in aqueous fluids. Some of the detoxification products of myrcene have been used as pheromones, but there appears to have been a selection for beetles that can synthesize these pheromone components from mevalonate (Byers and Birgersson, 1990; Ivarsson et al., 1993). In I. paraconfusus the production of ipsenol and ipsdienol in males is not primarily for detoxification of myrcene since the conversion is sex-specific, inhibited by streptomycin or mating with females, and induced by juvenile hormone. On the other hand, the cis-verbenol synthesis is primarily a detoxification process since the compound is not sex-specific (although males produce more cis-verbenol) and juvenile hormone, streptomycin or mating have no effect on its production (Hughes and Renwick, 1977; Byers et al., 1979; Byers 1981a, 1981b, 1983b; Byers and Wood, 1981a; Hunt and Borden, 1989). Other than cis-verbenol and possibly trans-verbenol, no other bark beetle pheromone components (Fig. 5.5) are 
thought to be primarily a detoxification of monoterpenes, but rather are synthesized de novo from acetate or mevalonate (Vanderwel and Oehlschlager, 1987; Lanne et al., 1989; Ivarsson et al., 1993).

A case where coevolution may still occur is in I. paraconfusus and I. typographus that rely on host tree (-)- $\alpha$-pinene as the precursor of cis-verbenol. However, I. typographus is relatively insensitive to large variations in the proportion of $c i s$-verbenol to methyl butenol in the pheromone blend (Schlyter et al. 1987c), indicating that most Norway spruce are adequate hosts regardless of their $\alpha$ pinene content. Thus, a tree genotype that produced less (-)- $\alpha$-pinene might not gain an advantage since beetles could still produce adequate pheromone to cooperate in killing the tree. Certainly, the large number of beetle generations relative to the tree would allow the genes of beetles to track any changes in the host and compensate in production and/or response. Presumably the benefits of $\alpha$-pinene for the tree, such as its toxicity to beetles and microorganisms discussed earlier, also would counter any tendency to select trees with a lower titer of $\alpha$ pinene.

Several authors have suggested that some plants have evolved an indirect tritrophic mechanism of resistance in which they release compounds (synomones) after being fed upon that are attractive to predators or parasites of their herbivores (Turlings et al., 1990; Whitman and Eller, 1990). The plant could gain benefits if their herbivores are not attracted by these same host volatiles. However, the same host compounds that are attractive to the predators and parasites of bark beetles are often attractive to bark beetles as well. For example, Enoclerus lecontei (Cleridae) and Temnochila virescens (Ostomidae) prey on several bark beetles such as $D$. brevicomis and $I$. paraconfusus in California. The predators are attracted to several monoterpenes or $\mathrm{n}$-heptane (Jeffrey pine) (Mirov, 1961) from host trees of bark beetles (Rice, 1969; Pitman and Vité, 1971). A clerid predator in Europe, Thanasimus formicarius preys on 1. typographus of Norway spruce and $T$. piniperda of Scots pine and is also attracted to $\alpha$-pinene and other monoterpenes from these conifers (Schroeder, 1988; Schroeder and Lindelöw, 1989). The dipteran parasites Medetera aldrichii of $D$. pseudotsugae and $M$. bistriata of $D$. frontalis are attracted to the host-tree monoterpene, $\alpha$-pinene, presumably aiding in their location of attacked trees (Williamson, 1971; Fitzgerald and Nagel, 1972). These plant monoterpenes are attractive to many bark beetles, or are synergists of attractive pheromone components (see section 2.3). Thus, it seems doubtful that the tree would benefit by producing chemicals that attract bark beetle enemies as well as predators and parasites of these beetles. In this case the host compounds are better thought of as kairomones, i.e., chemicals that are used by receiving individuals to gain advantages. Kairomones are not dispensed with by the plant over evolutionary time because they confer advantages, such as insect resistance, that outweigh any disadvantages of them attracting additional herbivores.

Other parasites and predators of bark beetles are most strongly attracted to 
volatiles produced by their host bark beetle, although some of the attractive compounds may be derived from monoterpene precursors in the tree. Temnochila virescens feeds on $D$. brevicomis and the predator is almost as sensitive to exobrevicomin as is the bark beetle to this pheromone component (Pitman and Vité, 1971; Byers, 1988). However, in Texas T. virescens is more attracted to a mixture of Ips components (ipsdienol, ipsenol, and cis-verbenol) than to exobrevicomin (Billings and Cameron, 1984). Clerid beetles such as Thanasimus formicarius are generalist predators of bark beetles, feeding on several species and are attracted to (or perceive) compounds of Ips (ipsenol, ipsdienol, cisverbenol), Trypodendron (lineatin), and Dendroctonus/Dryocoetes (exo-brevicomin) (Bakke and Kvamme, 1981; Hansen, 1983; Kohnle and Vité, 1984; Lanne et al., 1987; Tommerås, 1988).

\section{Conclusions}

Of the 6,000 bark beetle species worldwide, in a particular geographic area there are usually from only a few to some tens of species that colonize any given species of tree, and then only one or a few species that can attack and kill the tree. Each host-tree species has a large variety of chemicals, some of which affect the success of the bark beetle in finding and colonizing its host tree. Bark beetles probably orient to attractive semiochemical sources during flight using odor-modulated anemotaxis, as in moths, but little is known about this process. It is better understood how beetles orient upwind during walking to attractive sources. Most studies have observed chemotaxis in arenas for the purpose of isolating pheromones rather than from the standpoint of basic behavior.

Bark beetles find suitable host trees by orienting to host odors, especially ethanol and monoterpenes, as well as to aggregation pheromones. However, very few studies could be characterized as complete or rigorous because the attractive compounds were discovered usually by screening of semiochemicals previously known for other species. Other studies have selected compounds for testing based on their presence in the insect or related species, but it is likely that many bioactive compounds have been overlooked. Also, blends of compounds have rarely been tested for synergism. Tree volatiles that attract predators and parasites of bark beetles are often the same as those that attract their host, i.e., most of these chemicals have been discovered by chance when testing compounds on bark beetles. Feeding stimulants and deterrents of conifer bark beetles have been isolated in various solvent fractions but not identified. Several compounds that elicit or deter feeding in deciduous bark beetles have been identified, but undoubtedly many behaviorally active compounds remain to be discovered. It is likely that behavioral responses of bark beetles within a species to semiochemicals may vary geographically as well as the semiochemicals produced by the bark beetles and the host trees. 
Fractionation of a biological extract by chromatographic methods (usually GC) and then recombination of certain fractions with an additive method has been used to test for synergism among semiochemicals in a behavioral bioassay. This method was used to isolate some of the first multicomponent pheromones of bark beetles (Silverstein et al., 1966, 1967; 1968; Pearce et al., 1975). However, due to the substantial work involved with these classical isolation methods, most studies have discovered semiochemicals by screening or comparative methods which are inherently less rigorous and are dependent on chromatographic resolution. The subtractive method, where each of the fractions is subtracted from the blend and tested such that blends with lowered activity indicate subtracted synergists, should aid in isolation of synergistic semiochemicals that otherwise have been hard to detect (Byers et al., 1990a; Byers, 1992c).

Future studies should be careful to report the release rates of test volatiles, and in many cases these should be adjusted to coincide with natural rates (Byers, 1988). This means that measurements of volatile release of semiochemicals must be done in many bark beetle systems for both host- and beetle-released semiochemicals (Birgersson and Bergström, 1989). When testing semiochemicals in the field, the spatial and temporal variation of responding insect populations with respect to trap placement may lead to erroneous conclusions. To counter this potential problem, relatively numerous trap replications have been previously employed; however, the mechanical slow rotation of a pair of traps (1-2 rph at 6-m separation) can even this catch variation (Byers et al., 1990b).

Resistance of trees has been studied for many years and monoterpenes, such as limonene, are implicated in their resistance to bark beetles and their symbiotic microorganisms (mostly fungi). However, there has been little recent toxicological work and the relative importance of the purported toxins remains to be established. Also, the monoterpenes have been tested at much higher vapor concentrations than those in nature, and they have not been evaluated in diets. Synergism or interactions between various toxins have not been investigated. Also, geographic variation in toxicity of host compounds has been little studied. A correlation between high-limonene trees and historical "predation" by bark beetles has been suggested as an example of host-chemical evolution. However, more studies are needed in stands with ongoing outbreaks of bark beetle to determine if natural selection can alter the genetic frequencies in the population of trees, and at the same time if populations of bark beetle change their tolerance to particular monoterpenes that were initially most toxic.

Host-tree monoterpenes $\alpha$-pinene and myrcene can be converted by a simple hydroxylation to ipsenol, ipsdienol, cis-verbenol and trans-verbenol, pheromone components of bark beetles. However, $I$. paraconfusus is able to make the same amounts of ipsenol and ipsdienol regardless of the myrcene titer in the host tree, suggesting the major pathway is de novo. Recent studies in Ips species also suggest that pheromonal analogues of myrcene may not be derived primarily from myrcene but by synthesis from mevalonate. Although ipsenol/ipsdienol and 
$E$-myrcenol biosynthesis in some species of bark beetle are probably not coevolving with myrcene in the tree, it is possible that cis-and trans-verbenol biosynthesis may coevolve with $\alpha$-pinene levels in hosts. Both cis-verbenol and trans-verbenol appear to be directly produced in bark beetles by conversion of $\alpha$-pinene enantiomers from the host tree. However, verbenone, an inhibitor of aggregation in many bark beetle species, may not be directly converted from $\alpha$-pinene. Other bark beetle pheromone components are probably biosynthesized from small molecules into the more complex structures in several or more different biosynthetic pathways.

Evolution of tree chemistry in response to predation by bark beetles is best supported in studies of host compounds that are toxic to bark beetles or that deter feeding. Bark beetles have also coevolved detoxification mechanisms for the toxic monoterpenes, some of which have been secondarily utilized as pheromone components. Volatile host attractants can be termed kairomones, and there is little evidence that trees evolve these compounds to repel herbivores not adapted to this potential host, since the same compounds attract their herbivores. The compounds probably are beneficial in some way to the tree and cannot be dispensed with even though bark beetles (and some of their predators and parasites) have evolved to utilize the compounds as kairomones. Host-tree chemistry affects most aspects of bark beetle biology, moreover, bark beetles probably differentially affect survival of host trees and alter genotypic frequencies and host chemistry both at the microevolutionary scale (cycling of endemic and epidemic insect populations) and at the macroevolutionary level (host-tree selection in response to new species of bark beetle).

\section{Acknowledgments}

The chapter was improved by reviews from O. Anderbrant and F. Schlyter, Department of Animal Ecology, Lund University; G. Birgersson and P. Ivarsson, Department of Chemical Ecology, Göteborg University; L.M. Schroeder, A. Lindelöw, and J. Weslien, Department of Forest Entomology, Sweden's Agricultural University, Sweden; K. Hobson, USDA Forest Service, Logan, Utah; and the editors. The review was supported in part by a grant from SJFR (Sweden).

\section{References}

Akers, R. P. (1989) Counterturns initiated by decrease in rate of increase of concentration: possible mechanism of chemotaxis by walking female Ips paraconfusus bark beetles. J. Chem. Ecol. 15: 183-208.

Akers, R. P. and Wood, D. L. (1989a) Olfactory orientation responses by walking female Ips paraconfusus bark beetles I. Chemotaxis assay. J. Chem. Ecol. 15: 3-24.

Akers, R. P. and Wood, D. L. (1989b) Olfactory orientation responses by walking female 
Ips paraconfusus bark beetles II. In an anemotaxis assay. J. Chem. Ecol. 15: 11471160.

Anderbrant, O. (1985) Dispersal of reemerged spruce bark beetles, Ips typographus (Coleoptera, Scolytidae): a mark-recapture experiment. Z. Angew. Entomol. 99: 2125.

Anderson, A. B. (1962) The influence of extractives on tree properties II. Ponderosa pine (Pinus ponderosa Dougl.). J. Inst. Wood Sci. 10: 29-47.

Anderson, A. B., Riffer, R., and Wong, A. (1969) Monoterpenes, fatty and resin acids of Pinus ponderosa and Pinus jeffreyi. Phytochemistry 8: 873-875.

Anderson, W. W., Berisford, C. W., and Kimmich, R. H. (1979) Genetic differences among five populations of the southern pine beetle. Ann. Entomol. Soc. Am. 72: 323327.

Anderson, W. W., Berisford, C. W., Tumbow, R. H. and Brown, C. J. (1983) Genetic differences among populations of the black turpentine beetle, Dendroctonus terebrans, and an engraver beetle, Ips calligraphus (Coleoptera: Scolytidae). Ann. Entomol. Soc. Am. 76: 896-902.

Atkins, M. D. (1969) Lipid loss with flight in the Douglas-fir beetle. Can. Entomol. 101: 164-165.

Austarå, O., Bakke, A., and Midtgaard, F. (1986) Response in Ips typographus to logging waste odors and synthetic pheromones. J. Appl. Entomol. 101: 194-198.

Baker, B. H., Hostetler, B. B., and Furniss, M. M. (1977) Response of eastern larch beetle (Coleoptera: Scolytidae) in Alaska to its natural attractant and to Douglas-fir beetle pheromones. Can. Entomol. 109: 289-294.

Baker, J. E. and Norris, D. M. (1967) A feeding stimulant for Scolytus multistriatus (Coleoptera: Scolytidae) isolated from the bark of Ulmus americana. Ann. Entomol. Soc. Am. 60: 1213-1215.

Baker, J. E. and Norris, D. M. (1968) Further biological and chemical aspects of host selection by Scolytus multistriatus. Ann. Entomol. Soc. Am. 61: 1248-1255.

Baker, T. C. (1989) Sex pheromone communication in the Lepidoptera: new research progress. Experientia 45: 248-262.

Baker, T. C., Hansson, B. S., Löfstedt, C., and Löfqvist, J. (1988) Adaptation of antennal neurones in moths is associated with cessation of pheromone-mediated upwind flight. Proc. Natl. Acad. Sci. USA 85: 9826-9830.

Bakke, A. (1975) Aggregation pheromone in the bark beetle Ips duplicatus (Sahlberg). Norw. J. Entomol. 22: 67-69.

Bakke, A. (1981) Inhibition of the response in Ips typographus to the aggregation pheromone; field evaluation of verbenone and ipsenol. Z. Angew. Entomol. 92: 172-177.

Bakke, A. (1983) Dosage response of the ambrosia beetle Trypodendron lineatum (Oliver) (Coleoptera, Scolytidae) to semiochemicals. Z. Angew. Entomol. 95: 158-161.

Bakke, A. and Kvamme, T. (1981) Kairomone response in Thanasimus predators to pheromone components of lps typographus. J. Chem. Ecol. 7: 305-312. 
Bakke, A., Fryen, P., and Skattebl, L. (1977) Field response to a new pheromonal compound isolated from Ips typographus. Naturwissenschaften 64: 98.

Bedard, W. D., Tilden, P. E., Wood, D. L., Silverstein, R. M., Brownlee, R. G., and Rodin, J. O. (1969) Western pine beetle: field response to its sex pheromone and a synergistic host terpene, myrcene. Science 164: 1284-1285.

Bedard, W. D., Silverstein, R. M. and Wood, D. L. (1970) Bark beetle pheromones. Science 167: 1638-1639.

Begley, M.J. and Grove, J.F. 1985. Metabolic products of Phomopsis oblonga I. 3a,5a,6,7,8,9,9a,9b-octahydro-7,9b-dimethylnaphtho-1,2-c-furan-1-3h-one oblongolide. J. Chem. Soc. Perkin Trans. I. 0: 861-864.

Bennett, R. B. and Borden, J. H. (1971) Flight arrestment of tethered Dendroctonus pseudotsugae and Trypodendron lineatum (Coleoptera: Scolytidae) in response to olfactory stimuli. Ann. Entomol. Soc. Am. 64: 1273-1286.

Berenbaum, M. R. and Isman, M. B. (1989) Herbivory in holometabolous and hemimetabolous insects: Contrasts between Orthoptera and Lepidoptera. Experientia 45: 229236.

Berryman, A. A. (1969) Responses of Abies grandis to attack by Scolytus ventralis (Coleoptera: Scolytidae). Can. Entomol. 101: 1033-1041.

Berryman, A. A. (1972) Resistance of conifers to invasion by bark beetle-fungi associations. Bioscience 22: 598-602.

Berryman, A. A. and Ashraf, M. (1970) Effects of Abies grandis resin on the attack behavior and brood survival of Scolytus ventralis (Coleoptera: Scolytidae). Can. Entomol. 102: 1229-1236.

Berryman, A. A., Dennis, B., Raffa, K. F., and Stenseth, N. C. (1985) Evolution of optimal group attack with particular reference to bark beetles (Coleoptera: Scolytidae). Ecology 66: 898-903.

Billings, R. F. and Cameron, R. S. (1984) Kairomonal responses of Coleoptera: Monochamus titillator (Cerambycidae), Thanasimus dubius (Cleridae) and Temnochila virescens (Trogositidae) to behavioral chemicals of southern pine bark beetles Dendroctonus frontalis (Coleoptera: Scolytidae). Environ. Entomol. 13: 1542-1548.

Birch, M. C. (1984) Aggregation in bark beetles. In: Chemical Ecology of Insects (Bell, W. J. and Carde, R. T., eds.) pp. 331-353. Chapman and Hall, London.

Birch, M. C., Light, D. M., Wood, D. L., Browne, L. E., Silverstein, R. M., Bergot, B. J., Ohloff, G., West, J. F. and Young, J. C. (1980a) Pheromonal attraction and allomonal interruption of Ips pini in California by the two enantiomers of ipsdienol. J. Chem. Ecol. 6: 703-717.

Birch, M. C., Svihra, P., Paine, T. D. and Miller, J. C. (1980b) Influence of chemically mediated behavior on host tree colonization by four cohabiting species of bark beetles. J. Chem. Ecol. 6: 395-414.

Birgersson, G. and Bergström, G. (1989) Volatiles released from individual spruce bark beetle entrance holes: quantitative variations during the first week of attack. J. Chem. Ecol. 15: 2465-2484. 
Birgersson, G. and Leufvén, A. (1988) The influence of host tree response to lps typographus and fungal attack on production of semiochemicals. Insect Biochem. 18: 761770 .

Birgersson, G., Schlyter, F., Löfqvist, J., and Bergström, G. (1984) Quantitative variation of pheromone components in the spruce bark beetle lps typographus from different attack phases. J. Chem. Ecol. 10: 1029-1055.

Birgersson, G., Byers, J. A., Bergström, G., and Löfqvist, J. (1990) Production of pheromone components, chalcogran and methyl $(E, Z)-2,4$-decadienoate, in the spruce engraver Pityogenes chalcographus. J. Insect Physiol. 36: 391-395.

Bombosch, S., Engler, I., Gossenauer, H., and Herrmann, B. (1985) On the role of pheroprax influencing the settlement of lps typographus on spruce. Z. Angew. Entomol. 100: 458-463.

Bordasch, R. P. and Berryman, A. A. (1977) Host resistance to the fir engraver beetle, Scolytus ventralis (Coleoptera: Scolytidae) 2. repellency of Abies grandis resins and some monoterpenes. Can. Entomol. 109: 95-100.

Borden, J. H. (1982) Aggregation pheromones. In: Bark beetles in North American Conifers: A System for the Study of Evolutionary Biology (Mitton, J. B. and Sturgeon, K. M., eds.) pp. 74-139. Univ. Texas Press, Austin, Tex.

Borden, J. H. and Wood, D. L. (1966) The antennal receptors and olfactory response of lps confusus (Coleoptera: Scolytidae) to male sex attractant in the laboratory. Ann. Entomol. Soc. Am. 59: 253-261.

Borden, J. H., Handley, J. R., McLean, J. A., Silverstein, R. M., Chong, L., Slessor, K. N., Johnston, B. D., and Schuler, H. R. (1980) Enantiomer-based specificity in pheromone communication by two sympatric Gnathotrichus species (Coleoptera: Scolytidae). J. Chem. Ecol. 6: 445-456.

Borden, J. H., Chong, L., Slessor, K. N., Oehlschlager, A. C., Pierce, Jr., H. D., and Lindgren, B. S. (1981) Allelochemic activity of aggregation pheromones between three sympatric species of ambrosia beetles (Coleoptera: Scolytidae). Can. Entomol. 113: 557-563.

Borden, J. H., King, C. J., Lindgren, S., Chong, L., Gray, D. R., Oehlschlager, A. C., Slessor, K. N., and Pierce, Jr., H. D. (1982) Variation in response of Trypodendron lineatum from two continents to semiochemicals and trap form. Environ. Entomol. 11: 403-408.

Borden, J. H., Hunt, D. W. A., Miller, D. R., and Slessor, K. N. (1986) Orientation in forest Coleoptera: An uncertain outcome of responses by individual beetles to variable stimuli. In: Mechanisms in Insect Olfaction (Payne, T. L., Birch, M. C., and Kennedy, C. E. J., eds.) pp. 97-109. Clarendon Press, Oxford, U.K.

Borden, J. H., Pierce, A. M., Pierce, Jr., H. D., Chong, L. J., Stock, A. J., and Oehlschlager, A. C. (1987) Semiochemicals produced by western balsam bark beetle Dryocoetes confusus Swaine (Coleoptera: Scolytidae). J. Chem. Ecol. 13: 823-836.

Borg, T. K. and Norris, D. M. (1971) Penetration of tritiated catechol: A feeding stimulant into chemo receptor sensilla of Scolytus multistriatus (Coleoptera: Scolytidae). Ann. Entomol. Soc. Am. 64: 544-547. 
Botterweg, P. F. (1982) Dispersal and flight behavior of the spruce bark beetle Ips typographus in relation to sex, size and fat content. Z. Angew. Entomol. 94: 466-489.

Brand, J. M., Bracke, J. W., Markovetz, A. J., Wood, D. L., and Browne, L. E. (1975) Production of verbenol pheromone by a bacterium isolated from bark beetles. Nature 254: 136-137.

Brand, J. M., Bracke, J. W., Britton, L. N., Markovetz, A. J., and Barras, S. J. (1976) Bark beetle pheromones: production of verbenone by a mycangial fungus of Dendroctonus frontalis. J. Chem. Ecol. 2: 195-199.

Bridges, J. R. (1987) Effects of terpenoid compounds on growth of symbiotic fungi associated with the southern pine beetle. Phytopathology 77: 83-85.

Bridges, J. R. and Perry, T. J. (1985) Effects of mycangial fungi on gallery construction and distribution of bluestain in southem pine beetle Dendroctonus frontalis infested pine bolts. J. Entomol. Sci. 20: 271-275.

Bridges, J. R., Nettleton, W. A., and Connor, M. D. (1985) Southern pine beetle Dendroctonus frontalis (Coleoptera: Scolytidae) infestations without the bluestain fungus Ceratocystis minor. J. Econ. Entomol. 78: 325-327.

Brown, M. W., Nebeker, T. E., and Honea, C. R. (1987) Thinning increases loblolly pine vigor and resistance to bark beetles. South. J. Appl. For. 11: 28-31.

Burghardt, G. M. (1970) Defining "communication." In: Communication by Chemical Signals (Johnstron, Jr., J. W., Moulton, D. G. and Turk, A., eds.) pp. 5-18. Appleton, New York.

Byers, J. A. (1981a) Effect of mating on terminating aggregation during host colonization in the bark beetle, Ips paraconfusus. J. Chem. Ecol. 7: 1135-1147.

Byers, J. A. (1981b) Pheromone biosynthesis in the bark beetle, lps paraconfusus, during feeding or exposure to vapours of host plant precursors. Insect Biochem. 11: 563-569.

Byers, J. A. (1982) Male-specific conversion of the host plant compound, myrcene, to the pheromone, (+)-ipsdienol, in the bark beetle, Dendroctonus brevicomis. J. Chem. Ecol. 8: 363-372.

Byers, J. A. (1983a) Bark beetle conversion of a plant compound to a sex-specific inhibitor of pheromone attraction. Science 220: 624-626.

Byers, J. A. (1983b) Influence of sex, maturity and host substances on pheromones in the guts of the bark beetles, Dendroctonus brevicomis and Ips paraconfusus. J. Insect Physiol. 29: 5-13.

Byers, J. A. (1983c) Sex-specific responses to aggregation pheromone: Regulation of colonization density by the bark beetle Ips paraconfusus. J. Chem. Ecol. 9: 129-142.

Byers, J. A. (1984) Nearest neighbor analysis and simulation of distribution patterns indicates an attack spacing mechanism in the bark beetle, Ips typographus (Coleoptera: Scolytidae). Environ. Entomol. 13: 1191-1200.

Byers, J. A. (1988) Novel diffusion-dilution method for release of semiochemicals: testing pheromone component ratios on western pine beetle. J. Chem. Ecol. 14: 199-212.

Byers, J. A. (1989a) Behavioral mechanisms involved in reducing competition in bark beetles. Holarc. Ecol. 12, 466-476. 
Byers, J. A. (1989b) Chemical ecology of bark beetles. Experientia 45: 271-283.

Byers, J. A. (1992a) Attraction of bark beetles, Tomicus piniperda, Hylurgops palliatus, and Trypodendron domesticum and other insects to short-chain alcohols and monoterpenes. J. Chem. Ecol. 18: 2385-2402.

Byers, J. A. (1992b) Dirichlet tessellation of bark beetle spatial attack points. J. Anim. Ecol. 61: 759-768.

Byers, J. A. (1992c) Optimal fractionation and bioassay plans for isolation of synergistic chemicals: the subtractive-combination method. J. Chem. Ecol. 18: 1603-1621.

Byers, J. A. (1993a) Avoidance of competition by spruce bark beetles, lps typographus and Pityogenes chalcographus. Experientia 49: 272-275.

Byers, J. A. (1993b) Simulation and equation models of insect population control by pheromone-baited traps. J. Chem. Ecol. 19: 1939-1956.

Byers, J. A. and Birgersson, G. (1990) Pheromone production in a bark beetle independent of myrcene precursor in host pine species. Naturwissenschaften 77: 385-387.

Byers, J. A. and Löfqvist, J. (1989) Flight initiation and survival in the bark beetle Ips typographus (Coleoptera: Scolytidae) during the spring dispersal. Holarc. Ecol. 12: $432-440$.

Byers, J. A. and Wood, D. L. (1980) Interspecific inhibition of the response of the bark beetles, Dendroctonus brevicomis and Ips paraconfusus, to their pheromones in the field. J. Chem. Ecol. 6: 149-164.

Byers, J. A. and Wood, D. L. (1981a) Antibiotic-induced inhibition of pheromone synthesis in a bark beetle. Science, $213,763-4$.

Byers, J. A. and Wood, D. L. (1981b) Interspecific effects of pheromones on the attraction of the bark beetles, Dendroctonus brevicomis and Ips paraconfusus in the laboratory. J. Chem. Ecol., 7, 9-18.

Byers, J. A., Wood, D. L., Browne, L. E., Fish, R. H., Piatek, B., and Hendry, L. B. (1979) Relationship between a host plant compound, myrcene and pheromone production in the bark beetle, Ips paraconfusus. J. Insect Physiol. 25: 477-482.

Byers, J. A., Wood, D. L., Craig, J., and Hendry, L. B. (1984) Attractive and inhibitory pheromones produced in the bark beetle, Dendroctonus brevicomis, during host colonization: Regulation of inter- and intraspecific competition. J. Chem. Ecol. 10: 861877.

Byers, J. A., Lanne, B. S., Schlyter, F., Löfqvist, J., and Bergström, G. (1985) Olfactory recognition of host-tree susceptibility by pine shoot beetles. Naturwissenschafien 72 : 324-326.

Byers, J. A., Birgersson, G., Löfqvist, J., and Bergström, G. (1988) Synergistic pheromones and monoterpenes enable aggregation and host recognition by a bark beetle. Naturwissenschaften 75: 153-155.

Byers, J. A., Anderbrant, O., and Löfqvist, J. (1989a) Effective attraction radius: A method for comparing species attractants and determining densities of flying insects. J. Chem. Ecol. 15: 749-765.

Byers, J. A., Högberg, H. E., Unelius, R., Birgersson, G., and Löfqvist, J. (1989b) 
Structure-activity studies on aggregation pheromone components of Pityogenes chalcographus (Coleoptera: Scolytidae): All stereoisomers of chalcogran and methyl 2,4decadienoate. J. Chem. Ecol. 15: 685-695.

Byers, J. A., Lanne, B. S., and Löfqvist, J. (1989c) Host-tree unsuitability recognized by pine shoot beetles in flight. Experientia 45: 489-492.

Byers, J. A., Birgersson, G., Löfqvist, J., Appelgren, M., and Bergström, G. (1990a) Isolation of pheromone synergists of bark beetle, Pityogenes chalcographus, from complex insect-plant odors by fractionation and subtractive-combination bioassay. $J$. Chem. Ecol. 16: 861-876.

Byers, J. A., Schlyter, F., Birgersson, G., and Francke, W. (1990b) E-myrcenol in Ips duplicatus: an aggregation pheromone component new for bark beetles. Experientia 46: 1209-1211.

Cade, S. C., Hrutfiord, B. F., and Gara, R. I. (1970) Identification of a primary attractant for Gnathotrichus sulcatus isolated from western hemlock logs. J. Econ. Entomol. 63: 1014-1015.

Camacho, A. D., Pierce, Jr., H. D. and Borden, J. A. (1993) Geometrical and optical isomerism of pheromones in two sympatric Dryocoetes species (Coleoptera: Scolytidae), mediates species specificity and response level. J. Chem. Ecol. 19: 2169-2182.

Cates, R. G. (1981) Host plant predictability and the feeding patterns of monophagous, oligophagous, and polyphagous insect herbivores. Oecologia 48: 319-326.

Chapman, J. A. (1972) Ommatidia numbers and eyes in scolytid beetles. Ann. Entomol. Soc. Am. 65: 550-553.

Chararas, C., Katoulas, M., and Koutroumpas, A. (1982) Feeding preference of Ruguloscolytus rugulosus bark beetle parasite of fruit trees. C. R. Seances Acad. Sci. Ser. III Sci. Vie. 294: 763-766.

Chénier, J. V. R. and Philogène, B. J. R. (1989) Field responses of certain forest Coleoptera to conifer monoterpenes and ethanol. J. Chem. Ecol. 15: 1729-1746.

Choudhury, J. H. and Kennedy, J. S. (1980) Light versus pheromone-bearing wind in the control of flight direction by bark beetles, Scolytus multistriatus. Physiol. Entomol. 5: 207-214

Christiansen, E., Waring, R. H., and Berryman, A. A. (1987) Resistance of conifers to bark beetle attack: searching for general relationships. For. Ecol. Manage. 22: 89106.

Claydon, N., Grove, J. F., and Pople, M. (1985) Elm bark beetle boring and feeding deterrents from Phomopsis oblonga. Phytochemistry 24: 937-944.

Cobb, Jr., F. W., Krstic, M., Zavarin, E. and Barber, Jr., H. W. (1968) Inhibitory effects of volatile oleoresin components on Fomes annosus and four Ceratocystis species. Phytopathology 58: 1327-1335.

Conn, J. E., Borden, J. H., Hunt, D. W. A., Holman, J., Whitney, H. S., Spanier, O. J., Pierce, Jr., H. D., and Oehlschlager, A. C. (1984) Pheromone production by axenically reared Dendroctonus ponderosae and Ips paraconfusus (Coleoptera: Scolytidae). J. Chem. Ecol. 10: 281-290. 
Cook, S. P. and Hain, F. P. (1987) Four parameters of the wound response of loblolly and shortleaf pines to inoculation with the blue-staining fungus associated with the southem pine beetle. Can. J. Bot. 65: 2403-2409.

Croteau, R., Gurkewitz, S., Johnson, M. A., and Fisk, H. J. (1987) Biochemistry of oleoresinosis. Monoterpene and diterpene biosynthesis in lodgepole pine saplings infected with Ceratocystis clavigera or treated with carbohydrate elicitors. Plant Physiol. 85: 1123-1128.

David, C. T., Kennedy, J. S., Ludlow, A. R., Perry, J. N., and Wall, C. (1982) A reappraisal of insect flight towards a distant point source of wind-borne odor. $J$. Chem. Ecol. 8: 1207-1215.

Dethier, V. G. (1982) Mechanisms of host-plant recognition. Entomol. exp. appl. 31: 49-56.

Dickens, J. C. (1981) Behavioural and electrophysiological responses of the bark beetle Ips typographus to potential pheromone components. Physiol. Entomol. 6: 251-262.

Dickens, J.C. (1986) Specificity in perception of pheromones and host odours in Coleoptera. In: Mechanisms in insect olfaction (Payne, T. L., Birch, M. C., and Kennedy, C. E. J., eds.). pp. 253-261. Clarendon Press, Oxford, U.K.

Dickens, J. C., Gutmann, A., Payne, T. L., Ryker, L. C., and Rudinsky, J. A. (1983) Antennal olfactory responsiveness of Douglas-fir beetle, Dendroctonus pseudotsugae Hopkins (Coleoptera: Scolytidae) to pheromones and host odors. J. Chem. Ecol. 9: 1383-1395.

Dickens, J. C., Payne, T. L., Ryker, L. C., and Rudinsky, J. A. (1985) Multiple acceptors for pheromonal enantiomers on single olfactory cells in the Douglas-fir beetle, Dendroctonus pseudotsugae Hopk. (Coleoptera: Scolytidae. J. Chem. Ecol. 11: 13591370.

Dickens, J. C., Billings, R. F., and Payne, T. L. (1992) Green leaf volatiles interrupt aggregation pheromone response in bark beetles infesting southern pines. Experientia 48: 523-524.

Doke, N. and Tomiyama, K. (1980) Suppression of the hypersensitive response of potato tuber protoplasts to hyphal wall components by water soluble glucans isolated from Phytophthora infestans. Physiol. Plant Pathol. 16: 177-186.

Doskotch, R. W., Mikhail, A. A., and Chatterii, S. K. (1973) Structure of the water soluble feeding stimulant for Scolytus multistriatus: A revision. Phytochemistry 12: 1153-1155.

Elkinton, J. S. and Wood, D. L. (1980) Feeding and boring behavior of the bark beetle Ips paraconfusus (Coleoptera: Scolytidae) on the bark of a host and non-host tree species. Can. Entomol. 112: 797-809.

Elkinton, J. S., Wood, D. L., and Hendry, L. B. (1980) Pheromone production by the bark beetle, Ips paraconfusus, in the non-host, white fir. J. Chem. Ecol. 6: 979-987.

Elkinton, J. S., Wood, D. L., and Browne, L. E. (1981) Feeding and boring behavior of the bark beetle, Ips paraconfusus, in extracts of ponderosa pine phloem. J. Chem. Ecol. 7: 209-220. 
Ehrlich, P. R. and Raven, P. H. (1965) Butterflies and plants: a study in coevolution. Evolution 8: 586-608.

Faucheux, M. J. (1989) Morphology of the antennal club in the male and female bark beetles Ips sexdentatus (Boem.) and Ips typographus L. (Coleoptera: Scolytidae). Ann. Sci. Nat. Zool. Biol. Anim. 10: 231-243.

Feeny, P. (1975) Biochemical coevolution between plants and their insect herbivores. In: Coevolution of Animals and Plants (Gilbert, L. E. and Raven, P. H., eds.) pp. 319. Univ. Texas Press, Austin, Tex.

Fish, R. H., Browne, L. E., Wood, D. L., and Hendry, L. B. (1979) Pheromone biosynthetic pathways: conversion of deuterium labelled ipsdienol with sexual and enantioselectivity in Ips paraconfusus Lanier. Tetrah. Lett. 17: 1465-1468.

Fitzgerald, T. D. and Nagel, W. P. (1972) Oviposition and larval bark-surface orientation of Medetera aldrichii (Diptera: Dolichopodidae): Response to a prey-liberated plant terpene. Ann. Entomol. Soc. Am. 65: 328-330.

Forsse, E. and Solbreck, C. (1985) Migration in the bark beetle Ips typographus L.: duration, timing and height of flight. $Z$. Angew. Entomol. 100: 47-57.

Funk, A. (1970) Fungal symbionts of the ambrosia beetle Gnathotrichus sulcatus. Can. J. Bot. 48: 1445-1448.

Furniss, M. M., Woo, J. Y., Deyrup, M. A., and Atkinson, T. H. (1987) Prothoracic mycangium on pine-infesting Pityoborus spp. (Coleoptera: Scolytidae). Ann. Entomol. Soc. Am. 80: 692-696.

Gilbert, B. L., Baker, J. E., and Norris, D. M. (1967) Juglone (5-hydroxy-1 ,4-napthoquinone) from Carya ovata, a deterrent to feeding by Scolytus multistriatus. J. Insect Physiol. 13: 1453-1459.

Goeden, R. D. and Norris, D. M. (1964) Attraction of Scolytus quadrispinosus (Coleoptera: Scolytidae) to Carya spp. for oviposition. Ann. Entomol. Soc. Am. 57: 141-146.

Goeden, R. D. and Norris, D. M. (1965) The behavior of Scolytus quadrispinosus (Coleoptera: Scolytidae) during the dispersal flight as related to its host specificities. Ann. Entomol. Soc. Am. 58: 249-252.

Goldhammer, D. S., Stephen, F. M., and Paine, T. D. (1991) The effect of the fungi Ceratocystis minor Hedgecock-Hunt, Ceratocystis minor var. barrasii Taylor, and SJB 122 on reproduction of the southern pine beetle Dendroctonus frontalis Zimmermann (Coleoptera: Scolytidae). Can. Entomol. 122: 407-418.

Gollob, L. (1980) Monoterpene composition in bark beetle-resistant loblolly pine. Naturwissenschaften 67: 409-410.

Graham, K. (1959) Release by flight exercise of a chemotropic response from photopositive domination in a scolytid beetle. Nature 184: 283-284.

Graham, K. (1968) Anaerobic induction of primary chemical attractancy for ambrosia beetles. Can. J. Zool. 46: 905-908.

Gray, B., Billings, R. F., Gara, R. I., and Johnsey, R. L. (1972) On the emergence and initial flight behaviour of the mountain pine beetle, Dendroctonus ponderosae, in eastern Washington. Z. Angew. Entomol. 71: 250-259. 
Gries, G., Nolte, R., and Sanders, W. (1989) Computer simulated host selection in Ips typographus. Entomol. exp. appl. 53: 211-217.

Groberman, L. J. and Borden, H. J. (1982) Electrophysiological response of Dendroctonus pseudotsugae and Ips paraconfusus (Coleoptera: Scolytidae) to selected wave length regions of the visible spectrum. Can. J. Zool. 60: 2180-2189.

Hain, F. P., Mawby, W. D., Cook, S. P., and Arthur, F. H. (1983) Host conifer reaction to stem invasion. Z. Angew. Entomol. 96: 247-256.

Hallberg, E. (1982) Sensory organs in Ips typographus (Insecta: Coleoptera)-fine structure of the sensilla of the maxillary and labial palps. Acta Zool. 63: 191-198.

Hanover, J. M. and Furniss, M. M. (1966) Monoterpene concentration in Douglas-fir in relation to geographic location and resistance to attack by the Douglas-fir beetle. U.S. Dep. Agric. For. Serv. Res. Pap. NC 6, pp. 23-28, Washington, D.C.

Hansen, K. (1983) Reception of bark beetle pheromone in the predaceous clerid beetle, Thanasimus formicarius (Coleoptera: Cleridae). J. Comp. Physiol. A. 150: 371-378.

Happ, G. M., Happ, C. M., and French, J. R. J. (1976) Ultrastructure of the mesonotal mycangium of an ambrosia beetle Xyleborus dispar (Coleoptera: Scolytidae). Int. J. Insect Morphol. Embryol. 5: 381-392.

Hendry, L. B., Piatek, B., Browne, L. E., Wood, D. L., Byers, J. A., Fish, R. H., and Hicks, R. A. (1980) In vivo conversion of a labelled host plant chemical to pheromones of the bark beetle Ips paraconfusus. Nature 284: 485.

Himejima, M., Hobson, K. R., Otsuka, T., Wood, D. L., and Kubo, I. (1992) Antimicrobial terpenes from oleoresin of ponderosa pine tree Pinus ponderosa: A defense mechanism against microbial invasion. J. Chem. Ecol. 18: 1809-1818.

Hobson, K. R., Wood, D. L., Cool, L. G., White, P. R., Ohtsuka, T., Kubo, I., and Zavarin, E. (1993) Chiral specificity in responses by the bark beetle Dendroctonus valens to host kairomones. J. Chem. Ecol. 19: 1837-1846.

Hodges, J. D. and Lorio, Jr., P. L. (1975) Moisture stress and composition of xylem oleoresin in loblolly pine. For. Sci. 21: 283-290.

Hodges, J. D., Elam, W. W., Watson, W. R., and Nebeker, T. E. (1979) Oleoresin characteristics and susceptibility of four southern pines to southern pine beetle (Coleoptera: Scolytidae) attacks. Can. Entomol. 111: 889-896.

Hodges, J. D., Nebeker, T. E., DeAngelis, J. D., Karr, B. L., and Blanche, C. A. (1985) Host resistance and mortality: A hypothesis based on the southern pine beetlemicroorganism-host interactions. Bull. Entomol. Soc. Am. 31: 31-35.

Horntvedt, R. E., Christiansen, H., Solheim, H., and Wang, S. (1983) Artificial inoculation with Ips typographus-associated bluestain fungi can kill healthy Norway spruce trees. Medd. Nor. Inst. Skogforsk., 38: 1-20.

Hughes, P. R. (1973) Dendroctonus: Production of pheromones and related compounds in response to host monoterpenes. Z. Angew. Entomol. 73: 294-312.

Hughes, P. R. (1974) Myrcene: A precursor of pheromones in Ips beetles. J. Insect Physiol. 20: 1271-1275. 
Hughes, P. R. and Renwick, J. A. A. (1977) Neural and hormonal control of pheromone biosynthesis in the bark beetle, Ips paraconfusus. Physiol. Entomol. 2: 117-123.

Hunt, D. W. A. and Borden, J. H. (1989) Terpene alcohol pheromone production by Dendroctonus ponderosae and Ips paraconfusus (Coleoptera: Scolytidae) in the absence of readily culturable microorganisms. J. Chem. Ecol. 15: 1433-1464.

Hynum, B. G. and Berryman, A. A. (1980) Dendroctonus ponderosae (Coleoptera: Scolytidae) pre-aggregation landing and gallery initiation on lodgepole pine. Can. Entomol. 112: 185-192.

Ivarsson, P., Schlyter, F., and Birgersson, G. (1993) Demonstration of de novo pheromone biosynthesis in lps duplicatus (Coleoptera: Scolytidae): inhibition of ipsdienol and $E$ myrcenol production by compactin. Insect Biochem. Mol. Biol. 23: 655-662.

Jactel, H. (1991) Dispersal and flight behavior of Ips sexdentatus (Coleoptera: Scolytidae) in pine forest. Ann. Sci. For. 48: 417-428.

Jactel, H. and Gaillard, J. (1991) A preliminary study of the dispersal potential of Ips sexdentatus Boem (Coleoptera: Scolytidae) with an automatically recording flight mill. J. Appl. Entomol. 112: 138-145.

Jones, R. G. and Brindley, W. A. (1970) Tests of eight rearing media for the mountain pine beetle, Dendroctonus ponderosae (Coleoptera: Scolytidae), from lodgepole pine. Ann. Entomol. Soc. Am. 63: 313-316.

Kajimura, H. and Hijii, N. (1992) Dynamics of the fungal symbionts in the gallery system and the mycangia of the ambrosia beetle Xylosandrus mutilatus Blandford (Coleoptera: Scolytidae) in relation to its life history. Ecol. Res. 7: 107-117.

Kimmerer, T. W. and Kozlowski, T. T. (1982) Ethylene, ethane, acetaldehyde and ethanol production by plants under stress. Plant Physiol. 69: 840-847.

Kinzer, G. W., Fentiman, Jr., A. F., Page, T. F., Foltz, R. L., Vité, J. P., and Pitman, G. B. (1969) Bark beetle attractants: identification, synthesis and field bioassay of a new compound isolated from Dendroctonus. Nature 211: 475-476.

Klimetzek, D. and Francke, W. (1980) Relationship between the enantiomeric composition of $\alpha$-pinene in host trees and the production of verbenols in Ips species. Experientia 36: $1343-1345$.

Klimetzek, D., Köhler, J., Vité, J. P., and Kohnle, U. (1986) Dosage response to ethanol mediates host selection by 'secondary' bark beetles. Naturwissenschaften 73: 270-272.

Kohnle, U. (1985) Investigations of chemical communication systems in secondary bark beetles. Z. Angew. Entomol. 100: 197-218.

Kohnle, U. and Vité, J. P. (1984) Bark beetle predators: Strategies in the olfactory perception of prey species by clerid and trogositid beetles. Z. Angew. Entomol. 98: 504-508.

Langor, D. W., Spence, J. R., and Pohl, G. R. (1990) Host effects on fertility and reproductive success of Dendroctonus ponderosae Hopkins (Coleoptera: Scolytidae). Evolution 44: 609-618.

Långström, B. (1983) Within tree development of Tomicus minor (Coleoptera: Scolytidae) in wind thrown scotch pine. Acta Entomol. Fenn. 42: 42-46. 
Långström, B. and Hellqvist, C. (1991) Shoot damage and growth losses following three years of Tomicus attacks in scots pine stands close to a timber storage site. Silva. Fenn. 25: 133-145.

Lanier, G. N. (1983) Integration of visual stimuli, host odorants, and pheromones by bark beetles and weevils in locating and colonizing host trees. In: Herbivorous Insects: Host-Seeking Behavior and Mechanisms (Ahmad, S., ed.) pp. 161-171. Academic Press, New York.

Lanier, G. N. and Burns, B. W. (1978) Barometric flux. Effects on the responsiveness of bark beetles to aggregation attractants. J. Chem. Ecol. 4: 139-147.

Lanier, G. N., Birch, M. C., Schmitz, R. F., and Furniss, M. M. (1972) Pheromones of Ips pini (Coleoptera: Scolytidae): Variation in response among three populations. Can. Entomol. 104: 1917-1923.

Lanier, G. N., Classon, A., Stewart, T., Piston, J. J., and Silverstein, R. M. (1980) Ips pini: The basis for interpopulational differences in pheromone biology. J. Chem. Ecol. 6: 677-687.

Lanne, B. S., Schlyter, F., Byers, J. A., Löfqvist, J., Leufvén, A., Bergström, G., Van Der Pers, J. N. C., Unelius, R., Baeckström, P., and Norin, T. (1987) Differences in attraction to semiochemicals present in sympatric pine shoot beetles, Tomicus minor and T. piniperda. J. Chem. Ecol. 13: 1045-1067.

Lanne, B. S., Ivarsson, P., Johnsson, P., Bergström, G., and Wassgren, A. B. (1989) Biosynthesis of 2-methyl-3-buten-2-ol a pheromone component of Ips typographus (Coleoptera: Scolytidae). Insect. Biochem. 19: 163-168.

Lekander, B., Bejer-Petersen, B., Kangas, E., and Bakke, A. (1977) The distribution of bark beetles in the Nordic countries. Acta. Entomol. Fenn. 32: 1-37.

Leufvén, A., Bergström, G., and Falsen, E. (1984) Interconversion of verbenols and verbenone by identified yeasts isolated from the spruce bark beetle Ips typographus. J. Chem. Ecol. 10: 1349-1361.

Leufvén, A., Bergström, G., and Falsen, E. (1988) Oxygenated monoterpenes produced by yeasts isolated from Ips typographus (Coleoptera: Scolytidae) and grown in phloem medium. J. Chem. Ecol. 14: 353-362.

Levieux, J., Cassier, P., Guillaumin, D., and Roques, A. (1991) Structures implicated in the transportation of pathogenic fungi by the european bark beetle Ips sexdentatus Boerner: Ultrastructure of a mycangium. Can. Entomol. 123: 245-254.

Light, D. M. and Birch, M. C. (1982) Bark beetle enantiomeric chemoreception: greater sensitivity to allomone than pheromone. Naturwissenschafien 69: 243-245.

Lindelöw, A. and Weslien, J. (1986) Sex-specific emergence of Ips typographus L. (Coleoptera: Scolytidae) and flight behavior in response to pheromone sources following hibernation. Can. Entomol. 118: 59-67.

Lindelöw, A., Risberg, B., and Sjodin, K. (1992) Attraction during flight of scolytids and other bark and wood-dwelling beetles to volatiles from fresh and stored spruce wood. Can. J. For. Res. 22: 224-228.

Lindgren, B. S., Borden, J. H., Chong, L., Friskie, L. M., and Orr, D. B. (1983) Factors 
influencing the efficiency of pheromone baited traps for three species of ambrosia beetles (Coleoptera: Scolytidae). Can. Entomol. 115: 303-314.

Lindström, M., Norin, T., Birgersson, G., and Schlyter, F. (1989) Variation of enantiomeric composition of $\alpha$-pinene in Norway spruce, Picea abies, and its influence on production of verbenol isomers by Ips typographus in the field. J. Chem. Ecol. 15: 541-548.

Lorio, Jr., P. L. (1986) Growth and differentiation balance: A basis for understanding southern pine beetle Dendroctonus frontalis and tree interactions. For. Ecol. Manage. 14: 259-274.

Löyttyniemi, K., Heliovaara, K., and Repo, S. (1988) No evidence of a population pheromone in Tomicus piniperda (Coleoptera: Scolytidae): A field experiment. Ann. Entomol. Fenn. 54: 93-95.

Magema, N., Gaspar, C., and Séverin, M. (1982) Efficacité de l'éthanol dans le piégeage du scolyte Trypodendron lineatum (Olivier, 1795)(Coleoptera, Scolytidae) et role des constituants terpeniques de l'epicea. Ann. Soc. R. Zool. Belg. 112; 49-60.

Mathre, D. E. (1964) Pathenogenicity of Ceratocystis ips and Ceratocystis minor to Pinus ponderosa. Contrib. Boyce Thompson Inst. 22: 363-388.

McLean, J. A. and Borden, J. H. (1977) Attack by Gnathotrichus sulcatus (Coleoptera: Scolytidae) on stumps and felled trees baited with sulcatol and ethanol. Can. Entomol. 109: $675-686$.

McMullen, L. H. and Atkins, M. D. (1962) On the flight and host selection of the Douglas-fir beetle, Dendroctonus pseudotsugae Hopk. (Coleoptera: Scolytidae). Can. Entomol. 94: 1309-1325.

Meyer, H. J. and Norris, D. M. (1967a) Behavioral responses by Scolytus multistriatus (Coleoptera: Scolytidae) to host- (Ulmus) and beetle-associated chemotactic stimuli. Ann. Entomol. Soc. Am. 60: 642-646.

Meyer, H. J. and Norris, D. M. (1967b) Vanillin and syringaldehyde as attractants for Scolytus multistriatus (Coleoptera: Scolytidae). Ann. Entomol. Soc. Am. 60: 858-859.

Meyer, H. J. and Norris, D. M. (1974) Lignin intermediates and simple phenolics as feeding stimulants for Scolytus multistriatus. J. Insect Physiol. 20: 2015-2021.

Miller, D. R. and Borden, J. H. (1990) $\beta$-Phellandrene: Kairomone for pine engraver Ips pini (Say)(Coleoptera: Scolytidae). J. Chem. Ecol. 16: 2519-2531.

Miller, D. R., Borden, J. H. , and Slessor, K. N. (1989) Interpopulation and intrapopulation variation of the pheromone ipsdienol produced by male pine engravers Ips pini Say (Coleoptera: Scolytidae). J. Chem. Ecol. 15: 233-248.

Miller, J. R. and Strickler, K. L. (1984) Finding and accepting host plants. In: Chemical Ecology of Insects (Bell, W. J. and Cardé, R. T., eds.) pp. 127-157. Chapman and Hall, London.

Mirov, N.T. (1961) Composition of gum turpentines of pines. USDA For. Ser. Tech. Bull. No. 1239, Washington, D.C.

Moeck, H. A. (1970) Ethanol as the primary attractant for the ambrosia beetle Trypodendron lineatum (Coleoptera: Scolytidae). Can. Entomol. 102: 985-994. 
Moeck, H. A. (1981) Ethanol induces attack on trees by spruce beetles Dendroctonus rufipennis (Coleoptera: Scolytidae). Can. Entomol. 113: 939-942.

Moeck, H. A., Wood, D. L., and Lindahl, Jr., K. Q. (1981) Host selection behavior of bark beetles (Coleoptera: Scolytidae) attacking Pinus ponderosa, with special emphasis on the western pine beetle, Dendroctonus brevicomis. J. Chem. Ecol. 7: 49-83.

Montgomery, M. E. and Wargo, P. M. (1983) Ethanol and other host derived volatiles as attractants to beetles that bore into hardwoods. J. Chem. Ecol. 9: 181-190.

Moser, J. C. and Browne, L. E. (1978) A nondestructive trap for Dendroctonus frontalis Zimmerman (Coleoptera: Scolytidae). J. Chem. Ecol. 4: 1-7.

Mustaparta, H. (1984) Olfaction. In: Chemical Ecology of Insects (Bell, W. J. and Cardé, R. T., eds.) pp. 37-70. Chapman and Hall, London.

Mustaparta, H., Angst, M. E., and Lanier, G. N. (1980) Receptor discrimination of enantiomers of the aggregation pheromone ipsdienol, in two species of Ips. J. Chem. Ecol. 6: 689-701.

Mustaparta, H., Tommerås, B. A., Baeckström, P., Bakke, J. M., and Ohloff, G. (1984) Ipsdienol-specific receptor cells in bark beetles: Structure activity relationships of various analogs and the deuterium-labeled ipsdienol. J. Comp. Physiol. A. 154: 591-596.

Namkoong, G., Roberds, J. H., Nunnally, L. B., and Thomas, H. A. (1979) Isozyme variations in populations of southern pine beetles. For. Sci. 25: 197-203.

Nijholt, W. W. and Shönherr, J. (1976) Chemical response behavior of scolytids in West Germany and western Canada. Can. For. Serv. Bi-mon. Res. Notes 32: 31-32.

Paine, T. D. (1984) Influence of the mycangial fungi of the western pine beetle Dendroctonus brevicomis on water conduction through ponderosa pine seedlings. Can. J. Bot. 62: 556-558.

Paine, T. D. and Stephen, F. M. (1987) Fungi associated with the southem pine beetle: Avoidance of induced defense response in loblolly pine. Oecologia 74: 377-379.

Paine, T. D. and Stephen, F. M. (1988) Induced defenses of loblolly pine, Pinus taeda: Potential impact on Dendroctonus frontalis within-tree mortality. Entomol. Exp. Appl. 46: 39-46.

Paine, T. D., Stephen, F. M. and Cates, R. G. (1988) Moisture stress, tree suitability, and southern pine beetle population dynamics. In: Integrated Control of Scolytid Bark Beetles (Payne, T. L. and Saarenmaa, H., eds.) pp. 85-103. Virginia Polytechnic Inst. and State Univ., Blacksburg, V.

Paiva, M. R. and Kiesel, K. (1985) Field responses of Trypodendron spp. (Col., Scolytidae) to different concentrations of lineatin and a-pinene. Z. Angew. Entomol. 99: 442448.

Payne, T. L. (1979) Pheromone and host odor perception in bark beetles. In: Neurotoxicology of Insecticides and Pheromones (Narahashi, T., ed.) pp. 27-57. Plenum Pub. Co., New York.

Payne, T. L. and Dickens, J. C. (1976) Adaptation to determine receptor system specificity in insect olfactory communication. J. Insect Physiol. 22: 1569-1572. 
Payne, T. L., Moeck, H. A., Willson, C. D., Coulson, R. N., and Humphreys, W. J. (1973) Bark beetle olfaction -II. Antennal morphology of sixteen species of Scolytidae (Coleoptera). Int. J. Insect Mor. Emb. 2: 177-192.

Payne, T. L., Richerson, J. V., Dickens, J. C., West, J. R., Mori, K., Berisford, C. W., Hedden, R. L., Vité, J. P., and Blum, M. S. (1982) Southern pine beetle: olfactory receptor and behavior discrimination of enantiomers of the attractant pheromone frontalin. J. Chem. Ecol. 8: 873-881.

Payne, T. L., Klimetzek, D., Kohnle, U. and Mori, K. (1983) Electrophysiological and field responses of Trypodendron-spp to enantiomers of lineatin. Z. Angew. Entomol. 95: 272-276.

Pearce, G. T., Gore, W. E., Silverstein, R. M., Peacock, J. W., Cuthbert, R. A., Lanier, G. N., and Simeone, J. B. (1975) Chemical attractants for the smaller European elm bark beetle, Scolytus multistriatus (Coleoptera: Scolytidae). J. Chem. Ecol. 1: 115124.

Phillips, T. W. (1990) Responses of Hylastes salebrosus to turpentine, ethanol and pheromones of Dendroctonus (Coleoptera: Scolytidae). Fla. Entomol. 73: 286-292.

Phillips, T. W., Wilkening, A. J., Atkinson, T. H., Nation, J. L., Wilkinson, R. C. and Foltz, J. L. (1988) Synergism of turpentine and ethanol as attractants for certain pine-infesting beetles (Coleoptera). Environ. Entomol. 17: 456-462.

Pierce, Jr., H. D., Conn, J. E., Oehlschlager, A. C., and Borden, J. H. (1987) Monoterpene metabolism in female mountain pine beetles, Dendroctonus ponderosae Hopkins attacking ponderosa pine. J. Chem. Ecol. 13: 1455-1480.

Pitman, G. B. (1969) Pheromone response in pine bark beetles: Influence of host volatiles. Science 166: 905-906.

Pitman, G. B. and Vité, J. P. (1969) Aggregation behavior of Dendroctonus ponderosae (Coleoptera: Scolytidae) in response to chemical messengers. Can. Entomol. 101: 143149.

Pitman, G. B. and Vité, J. P. (1971) Predator-prey response to western pine beetle attractants. J. Econ. Entomol. 64: 402-404.

Pitman, G. B. and Vité, J. P. (1974) Biosynthesis of methylcyclohexenone by male Douglas-fir beetle. Environ. Entomol. 3: 886-887.

Pitman, G. B., Renwick, J. A. A., and Vité, J. P. (1966) Studies on the pheromone of Ips confusus (LeConte). IV. Isolation of the attractive substance by gas-liquid chromatography. Contrib. Boyce Thompson Inst. 23: 243-250.

Pitman, G. B., Hedden, R. L., and Gara, R. 1. (1975) Synergistic effects of ethyl alcohol on the aggregation of Dendroctonus pseudotsugae (Col., Scolytidae) in response to pheromones. Z. Angew. Entomol. 78: 203-208.

Raffa, K. F. and Berryman, A. A. (1979) Flight responses and host selection by bark beetles. In: Dispersal of Forest Insects: Evaluation, Theory and Management Implications (Berryman, A. A. and Safranyik, L., eds.) pp. 213-233. Proc. second IUFRO conf., Canad. and USDA Forest Service, Washington State Univ., Pullman, W.

Raffa, K. F. and Berryman, A. A. (1982a) Accumulation of monoterpenes and associated 
volatiles following fungal inoculation of grand fir with a fungus vectored by the fir engraver Scolytus ventralis (Coleoptera: Scolytidae). Can. Entomol. 114: 797-810.

Raffa, K. F. and Berryman, A. A. (1982b) Gustatory cues in the orientation of Dendroctonus ponderosae (Coleoptera: Scolytidae) to host trees. Can. Entomol. 114: 97-104.

Raffa, K. F. and Berryman, A. A. (1982c) Physiological differences between lodgepole pines resistant and susceptible to the mountain pine beetle and associated microorganisms. Environ. Entomol. 11: 486-492.

Raffa, K. F. and Berryman, A. A. (1983) Physiological aspects of lodgepole pine wound responses to a fungal symbiont of the mountain pine beetle, Dendroctonus ponderosae (Coleoptera: Scolytidae). Can. Entomol. 115: 723-734.

Raffa, K. F. and Berryman, A. A. (1987) Interacting selective pressures in conifer-bark beetle systems: A basis for reciprocal adaptations? Am. Nat. 129: 234-262.

Raffa, K. F., Berryman, A. A., Simasko, J., Teal, W., and Wong, B. L. (1985) Effects of grand fir, Abies grandis monoterpenes on the fir engraver, Scolytus ventralis (Coleoptera: Scolytidae) and its symbiotic fungus. Environ. Entomol. 14: 552-556.

Raffa, K. F., Phillips, T. W., and Salom, S. M. (1993) Strategies and mechanisms of host colonization by bark beetles. In: Beetle-Pathogen Interactions in Conifer Forests (Schowalter, T. D. and Filip, G. M., eds.) pp. 103-128. Academic Press, London.

Ramisch, H. (1986) Host location by Trypodendron domesticum and Trypodendron lineatum (Coleoptera: Scolytidae). Z. Angew. Zool. 73: 159-198.

Reed, A. N., Hanover, J. W., and Furniss, M. M. (1986) Douglas-fir and westem larch: chemical and physical properties in relation to Douglas-fir bark beetle attack. Tree Physiol. 1: 277-288.

Reid, R. W., Whitney, H. S. and Watson, J. A. (1967) Reactions of lodgepole pine to attack by Dendroctonus ponderosae Hopkins and blue stain fungi. Can. J. Bot. 45: 1115-1126.

Renwick, J. A. A. and Vité, J. P. (1968) Isolation of the population aggregating pheromone of the southern pine beetle. Contrib. Boyce Thompson Inst. 24: 65-68.

Renwick, J. A. A. and Vité, J. P. (1969) Bark beetle attractants: Mechanisms of colonization by Dendroctonus frontalis. Nature 224: 1222-1223.

Renwick, J. A. A. and Vité, J. P. (1970) Systems of chemical communication in Dendroctonus. Contrib. Boyce Thompson Inst. 24: 283-292.

Renwick, J. A. A., Hughes, P. R., and Krull, I. S. (1976) Selective production of cisand trans-verbenol from (-)-and (+)- $\alpha$-pinene by a bark beetle. Science 191: 199201.

Rice, R. E. (1969) Response of some predators and parasites of Ips confusus (LeC.)(Coleoptera: Scolytidae) to olfactory attractants. Contrib. Boyce Thompson Inst. 24: 189194.

Richeson, J. S., Wilkinson, R. C., and Nation, J. L. (1970) Development of Ips calligraphus on foliage based diets. J. Econ. Entomol. 63: 1797-1799.

Rose, W. F., Billings, R. F. and Vite, J. P. (1981) Southem pine bark beetles Ips 
calligraphus: Evaluation of nonsticky pheromone trap designs for survey and research. Southwest. Entomol. 6: 1-9.

Rudinsky, J. A. (1966) Host selection and invasion by the Douglas-fir beetle, Dendroctonus pseudotsugae Hopkins, in coastal Douglas-fir forests. Can. Entomol. 98: 98-111.

Rudinsky, J. A., Novak, V., and Svihra, P. (1971) Attraction of the bark beetle Ips typographus L. to terpenes and a male-produced pheromone. Z. Angew. Entomol. 67: 179-188.

Rudinsky, J. A., Fumiss, M. M., Kline, L. N., and Schmitz, R. F. (1972) Attraction and repression of Dendroctonus pseudotsugae (Coleoptera: Scolytidae) by three synthetic pheromones in traps in Oregon and Idaho. Can. Entomol. 104: 815-822.

Rudinsky, J. A., Morgan, M. E., Libbey, L. M., and Putnam, T. B. (1974) Antiaggregative-rivalry pheromone of the mountain pine beetle, and a new arrestant of the southern pine beetle. Environ. Entomol. 3: 90-98.

Rudinsky, J. A., Ryker, L. C., Michael, R. R., Libbey, L. M., and Morgan, M. E. (1976) Sound production in Scolytidae: Female sonic stimulus of male pheromone release in two Dendroctonus beetles. J. Insect Physiol. 22: 1675-1681.

Salom, S. M. and Mclean, J. A. (1989) Influence of wind on the spring flight of Trypodendron lineatum Olivier (Coleoptera: Scolytidae) in a second-growth coniferous forest. Can. Entomol. 121: 109-120.

Salom, S. M. and Mclean, J. A. (1991) Environmental influences on dispersal of Trypodendron lineatum (Coleoptera: Scolytidae). Environ. Entomol. 20: 565-576.

Salonen, K. (1973) On the life cycle, especially on the reproduction biology of Blastophagus piniperda L. (Col., Scolytidae). Acta For. Fenn. 127: 1-72.

Schlyter, F. and Löfqvist, J. (1986) Response of walking spnuce bark beetles Ips typographus to pheromone produced in different attack phases. Entomol. exp. appl. 41:219230.

Schlyter, F., Birgersson, G., Byers, J. A., Löfqvist, J., and Bergström, G. (1987a) Field response of spruce bark beetle, Ips typographus, to aggregation pheromone candidates. J. Chem. Ecol. 13: 701-716.

Schlyter, F., Byers, J. A., and Löfqvist, J. A. (1987b) Attraction to pheromone sources of different quantity, quality, and spacing: Density-regulation mechanisms in bark beetle Ips typographus. J. Chem. Ecol. 13: 1503-1523.

Schlyter, F., Löfqvist, J., and Byers, J. A. (1987c) Behavioural sequence in the attraction of the bark beetle Ips typographus to pheromone sources. Physiol. Entomol. 12: 185196.

Schlyter, F., Birgersson, G., Byers, J. A. and Bakke, A. (1992) The aggregation pheromone of Ips duplicatus and its role in competitive interactions with $I$. typographus (Coleoptera: Scolytidae). Chemoecology 3: 103-112.

Schroeder, L. M. (1987) Attraction of the bark beetle Tomicus piniperda to Scots pine trees in relation to tree vigor and attack density. Entomol. exp. appl. 44: 53-58.

Schroeder, L. M. (1988) Attraction of the bark beetle Tomicus piniperda and some other bark- and wood-living beetles to the host volatiles $\alpha$-pinene and ethanol. Entomol. exp. appl. 46: 203-210. 
Schroeder, L. M. (1990) Duct resin flow in scots pine in relation to the attack of the bark beetle Tomicus piniperda L. (Coleoptera: Scolytidae). J. Appl. Entomol. 109: 105-112.

Schroeder, L. M. (1992) Olfactory recognition of nonhosts aspen and birch by conifer bark beetles Tomicus piniperda and Hylurgops palliatus. J. Chem. Ecol. 18: 15831593.

Schroeder, L. M. and Eidmann, H. H. (1987) Gallery initiation by Tomicus piniperda (Coleoptera: Scolytidae) on Scots pine trees baited with host volatiles. J. Chem. Ecol. 13: 1591-1599.

Schroeder, L. M. and Lindelöw, A. (1989) Attraction of scolytids and associated beetles by different absolute amounts and proportions of $\alpha$-pinene and ethanol. J. Chem. Ecol. 15: 807-818.

Schuh, B. A. and Benjamin, D. M. (1984) The chemical feeding ecology of Neodipron dubiosus Schedl, $N$. rugifrons Midd, and $N$. lecontei (Fitch) on Jack pine (Pinus banksiana Lamb.). J. Chem. Ecol. 10: 1071-1079.

Scriber, J. M. (1984) Host-plant suitability. In: Chemical Ecology of Insects (Bell, W. J. and Cardé, R. T., eds.) pp. 159-202. Chapman and Hall, London.

Shain, L. (1967) Resistance of sapwood in stems of loblolly pine to infection by Fomes annosus. Phytopathology 57: 1034-1045.

Shrimpton, D. M. (1973) Extractives associated with the wound response of lodgepole pine attacked by the mountain pine beetle and associated microorganisms. Can. J. Bot. 51: 527-534.

Silverstein, R. M., Rodin, J. O., and Wood, D. L. (1966) Sex attractants in frass produced by male Ips confusus in ponderosae pine. Science 154: 509-510.

Silverstein, R. M., Rodin, J. O., and Wood, D. L. (1967) Methodology for isolation and identification of insect pheromones with reference to studies on California fivespined Ips. J. Econ. Entomol. 60: 944-949.

Silverstein, R. M., Brownlee, R. G., Bellas, T. E., Wood, D. L., and Browne, L. E. (1968) Brevicomin: Principal sex attractant in the frass of the female western pine beetle. Science 159: 889-891.

Smith, L. V. and Zavarin, E. (1960) Free mono- and oligosaccharides of some California conifers. Tech. Assoc. Pulp Pap. Ind. 43: 218-221.

Smith, M. T., Busch, G. R., Payne, T. L. and Dickens, J. C. (1988) Antennal olfactory responsiveness of three sympatric Ips species [Ips avulsus (Eichhoff), Ips calligraphus (Germar), Ips grandicollis (Eichhoff)], to intra- and interspecific behavioral chemicals J. Chem. Ecol. 14: 1289-1304.

Smith, R. H. (1961) The fumigant toxicity of three pine resins to Dendroctonus brevicomis and D. jeffrei. J. Econ. Entomol. 54: 365-369.

Smith, R. H. (1964) Variation in the monoterpenes of Pinus ponderosa Laws. Science 143: 1337-1338.

Smith, R. H. (1965a) A physiological difference among beetles of Dendroctonus ponderosae $(=D$. monticolae $)$ and $D$. ponderosae $(=D$. jeffreyi). Ann. Entomol. Soc. Am. 58: $440-442$. 
Smith, R. H. (1965b) Effect of monoterpene vapors on the western pine beetle. J. Econ. Entomol. 58: 509-510.

Smith, R. H. (1966) The monoterpene composition of Pinus ponderosa xylem resin and of Dendroctonus brevicomis pitch tubes. For. Sci. 12: 63-68.

Smith, R. H. (1967) Variations in the monoterpene composition of the wood resin of Jeffrey, Washoe, Coulter and lodgepole pines. For. Sci. 13: 246-252.

Smith, R. H. (1968) Intratree measurements of the monoterpene composition of ponderosa pine xylem resin. For. Sci. 14: 418-419.

Smith. R. H. (1969) Local and regional variation in the monoterpenes of ponderosa pine xylem resin. USDA For. Ser. Res. Pap. PSW-56 p. 1-10, Berkeley, CA.

Städler, E. (1984) Contact chemoreception. In: Chemical Ecology of Insects (Bell, W. J. and Cardé, R. T., eds.) pp. 3-35. Chapman and Hall, London.

Stephen, F. M. and Paine, T. D. (1985) Seasonal patterns of host tree resistance to fungal associates of the southern pine beetle. Z. Angew. Entomol. 99: 113-122.

Stock, M. W. and Amman, G. D. (1980) Genetic differentiation among mountain pine beetle populations from lodgepole pine and ponderosa pine in northeast Utah. Ann. Entomol. Soc. Am. 73: 472-478.

Stock, M. W., Pitman, G. B., and Guenther, J. D. (1979) Genetic differences between Douglas-fir beetles (Dendroctonus pseudotsugae) from Idaho and coastal Oregon. Ann. Entomol. Soc. Am. 72: 394-397.

Struble, G. R. 1957. The fir engraver, a serious enemy of western true firs. U.S. Dep. Agric. Prod. Res. Rep. II., Washington, D. C.

Sturgeon, K. B. (1979) Monoterpene variation in ponderosa pine xylem resin related to western pine beetle predation. Evolution 33: 803-814.

Sturgeon, K. B. and Mitton, J. B. (1986) Allozyme and morphological differentiation of mountain pine beetles Dendroctonus ponderosae (Coleoptera: Scolytidae) associated with host tree. Evolution 40: 290-302.

Teale, S. A., Webster, F. X., Zhang, A., and Lanier, G. N. (1991) Lanierone: a new pheromone component from Ips pini (Coleoptera: Scolytidae) in New York. J. Chem. Ecol. 17: 1159-1176.

Thompson, S. N. and Bennett, R. B. (1971) Oxidation of fat during flight of male Douglas-fir beetles, Dendroctonus pseudotsugae. Insect Physiol. 17: 1555-1563.

Tilden, P. E., Bedard, W. D., Lindahl, Jr., K. Q., and Wood, D. L. (1983) Trapping Dendroctonus brevicomis: Changes in attractant release rate, dispersion of attractant, and silhouette. J. Chem. Ecol. 9: 311-321.

Tommerås, B. A. (1988) The clerid beetle Thanasimus formicarius is attracted to the pheromone of the ambrosia beetle Trypodendron lineatum. Experientia 44: 536-537.

Tommerås, B. A., Mustaparta, H., and Gregoire, J. C. (1984) Receptor cells in Ips typographus and Dendroctonus micans specific to pheromones of the reciprocal genus. J. Chem. Ecol. 10: 759-769.

Tuomi, J. and Augner, M. (1993) Synergistic selection of unpalatability in plants. Evolution 47: 668-672. 
Turlings, T. C. J., Tumlinson, J. H., and Lewis, W. J. (1990) Exploitation of herbivoreinduced plant odors by host-seeking parasitic wasps. Science 250: 1251-1253.

Vanderwel, D. and Oehlschlager, A. C. (1987) Biosynthesis of pheromones and endocrine regulation of pheromone production in Coleoptera. In: Pheromone Biochemistry (Prestwich, G. D. and Blomquist, G. J., eds.) pp. 175-215. Academic Press, New York.

Vité, J. P. (1961) The influence of water supply on oleoresin exudation pressure and resistance to bark beetle attack in Pinus ponderosa. Contrib. Boyce Thompson Inst. 21: 37-66.

Vitê, J. P. and Bakke, A. (1979) Synergism between chemical and physical stimuli in host selection by an ambrosia beetle. Naturwissenschaften 66, 528-529.

Vité, J. P. and Pitman, G. B. (1969) Insect and host odors in the aggregation of the western pine beetle. Can. Entomol. 101: 113-117.

Vité, J. P., Bakke, A., and Renwick, J. A. A. (1972) Pheromones in Ips (Coleoptera: Scolytidae): Occurrence and production. Can. Entomol. 104: 1967-1975.

Vité, J. P., Volz, H. A., Paiva, M. R., and Bakke, A. (1986) Semiochemicals in host selection and colonization of pine trees by the pine shoot beetle Tomicus piniperda. Naturwissenschaften 73: 39-40.

Volz, H. A. (1988) Monoterpenes governing host selection in the bark beetles Hylurgops palliatus and Tomicus piniperda. Entomol. exp. appl. 47: 31-36.

Wagner, M. R., Benjamin, D. M., Clancy, K. L., and Schuh, B. A. (1983) Influence of diterpene resin acids on feeding and growth of larch sawfly, Pristphora erichsonii (Hartig). J. Chem. Ecol. 9: 119-127.

Webb, J. L. (1906) The western pine destroying bark beetle. U.S. Dep. Agric. Bur. Entomol. Bul. 58, Pt. II, 30 pp., Washington, D.C.

Webb, J. W. and Franklin, R. T. (1978) Influence of phloem moisture on brood development of the southern pine beetle (Coleoptera: Scolytidae). Environ. Entomol. 7: 405410.

White, J. D. (1981) A bioassay for tunneling responses of southern pine beetles to host extractives. J. Georgia Entomol. Soc. 16: 484-492.

Whitehead, A. T. (1981) Ultrastructure of sensilla of the female mountain pine beetle Dendroctonus ponderosae (Coleoptera: Scolytidae). Int. J. Insect Morphol. Embryol. 10: $19-28$

Whitman, D. W. and Eller, F. (1990) Parasitic wasps orient to green leaf volatiles. Chemoecology 1: 69-75.

Whitney, H. S. (1982) Relationships between bark beetles and symbiotic organisms. In: Bark Beetles in North American Conifers: A System for the Study of Evolutionary Biology (Mitton, J. B. and Sturgeon, K. B., eds.) pp. 183-211. Univ. Texas Press, Austin, Tex.

Whitney, H. S. and Spanier, O. J. (1982) An improved method for rearing axenic mountain pine beetles Dendroctonus ponderosae (Coleoptera: Scolytidae). Can. Entomol. 114: 1095-1100. 
Whittaker, R. H. (1970) The biochemical ecology of higher plants. In: Chemical Ecology (Sondheimer, E. and Simeone, J. B., eds.) pp 43-70. Academic Press, New York.

Williamson, D. L. (1971) Olfactory discernment of prey by Medetera bistriata (Diptera: Dolichopodidae). Ann. Entomol. Soc. Am. 64: 586-589.

Witanachchi, J. P. and Morgan, F. D. (1981) Behavior of the bark beetle, Ips grandicollis, during host selection. Physiol. Entomol. 6: 219-223.

Wollerman, E. H. (1979) Dispersion and invasion by Scolytus multistriatus in response to pheromone. Environ. Entomol. 8: 1-5.

Wong, B. L. and Berryman, A. A. (1977) Host resistance to the fir engraver beetle. 3. Lesion development and containment of infection by resistant Abies grandis inoculated with Trichosporium symbioticum. Can. J. Bot. 55: 2358-2365.

Wood, D. L. (1962) Experiments on the interrelationship between oleoresin exudation pressure in Pinus ponderosa and attack by lps confusus (LeC.)(Coleoptera: Scolytidae). Can. Entomol. 94: 473-477.

Wood, D. L. (1982) The role of pheromones, kairomones, and allomones in the host selection and colonization behavior of bark beetles. Annu. Rev. Entomol. 27: 411446.

Wood, D. L. and Vité, J. P. (1961) Studies on the host selection behavior of Ips confusus (LeConte)(Coleoptera: Scolytidae) attacking Pinus ponderosa. Contrib. Boyce Thompson Inst. 21: 79-96.

Wood, D. L., Browne, L. E., Bedard, W. D., Tilden, P. E., Silverstein R. M., and Rodin, J. O. (1968) Response of lps confusus to synthetic sex pheromones in nature. Science 159: 1373-1374.

Wood, S. L. (1982) The bark and ambrosia beetles of North and Central America (Coleoptera: Scolytidae), a taxonomic monograph. Great Basin Naturalist Memoirs, Brigham Young Univ., Provo, Utah.

Wright, L. E., Berryman, A. A., and Gurusiddaiah, S. (1979) Host resistance to the fir engraver beetle, Scolytus ventralis (Coleoptera: Scolytidae). 4. Effect of defoliation on wound monoterpenes and inner bark carbohydrate concentrations. Can. Entomol. 111: 1255-1261. 